NBER WORKING PAPER SERIES

\title{
GEOGRAPHIC DISPERSION OF ECONOMIC SHOCKS: EVIDENCE FROM THE FRACKING REVOLUTION
}

\author{
James Feyrer \\ Erin T. Mansur \\ Bruce Sacerdote \\ Working Paper 21624 \\ http://www.nber.org/papers/w21624 \\ NATIONAL BUREAU OF ECONOMIC RESEARCH \\ 1050 Massachusetts Avenue \\ Cambridge, MA 02138 \\ October 2015
}

We thank Mahnum Shazad for excellent research assistance, Drillinginfo for providing the natural gas and oil production data, Liz Cascio for the shale play data, and the National Science Foundation for generous funding. The views expressed herein are those of the authors and do not necessarily reflect the views of the National Bureau of Economic Research.

NBER working papers are circulated for discussion and comment purposes. They have not been peerreviewed or been subject to the review by the NBER Board of Directors that accompanies official NBER publications.

(C) 2015 by James Feyrer, Erin T. Mansur, and Bruce Sacerdote. All rights reserved. Short sections of text, not to exceed two paragraphs, may be quoted without explicit permission provided that full credit, including $\odot$ notice, is given to the source. 
Geographic Dispersion of Economic Shocks: Evidence from the Fracking Revolution James Feyrer, Erin T. Mansur, and Bruce Sacerdote

NBER Working Paper No. 21624

October 2015

JEL No. E24,Q33,Q35,Q43

\begin{abstract}
$\underline{\text { ABSTRACT }}$
The combining of horizontal drilling and hydrofracturing unleashed a boom in oil and natural gas production in the US. This technological shift interacts with local geology to create an exogenous shock to county income and employment. We measure the effects of these shocks within the county where production occurs and track their geographic propagation. Every million dollars of oil and gas extracted produces $\$ 66,000$ in wage income, $\$ 61,000$ in royalty payments, and 0.78 jobs within the county. Outside the immediate county but within the region, the economic impacts are over three times larger. Within 100 miles of the new production, one million dollars generates $\$ 243,000$ in wages, $\$ 117,000$ in royalties, and 2.49 jobs. Thus, over a third of the fracking revenue stays within the regional economy. Our results suggest new oil and gas extraction led to an increase in aggregate US employment of 725,000 and a 0.5 percent decrease in the unemployment rate during the Great Recession.
\end{abstract}

James Feyrer

Department of Economics

Dartmouth College

6106 Rockefeller Hall

Hanover, NH 03755-3514

and NBER

james.feyrer@dartmouth.edu
Bruce Sacerdote

6106 Rockefeller Hall

Department of Economics

Dartmouth College

Hanover, NH 03755-3514

and NBER

Bruce.I.Sacerdote@ dartmouth.edu

Erin T. Mansur

Dartmouth College

100 Tuck Hall

Hanover, NH 03755

and NBER

erin.mansur@dartmouth.edu 


\section{Introduction}

The technological innovation of combining horizontal drilling with hydrofracturing has created an oil and natural gas boom within the United States. The combination of technological change and preexisting geology has generated large income shocks in many areas of the country. Employment in the mining industry grew by 60 percent during a period when overall US unemployment reached 10 percent. We use the fracking revolution to study how income and employment shocks propagate across geography and industries.

We measure county-level impacts of new oil and gas production caused by the fracking boom. Our identification strategy uses a comprehensive data set of annual production (appropriately instrumented) to measure the effects on income, employment and crime. Our data allow us to know the exact value of new production taken out of the ground in any county in a given year. Using measures of income from the Bureau of Labor Statistics (BLS) and the Internal Revenue Service (IRS), we can examine how much of the value of new production stays within the county where the production occurs.

These income effects take several forms. First, wages of workers in the resource extraction and transportation industries are directly impacted through participation in the extraction process. Second, landowners are paid royalties on the value of production taken from their land. Finally, we examine the impact on wages and employment in industries not directly related to oil and gas production.

The county may not be the ideal level of observation because workers and landowners may be located in counties adjacent to where new production is occurring. By examining the impact of new production at increasing distances we can track the propagation of the shocks over space. This spatial analysis is important 
because we are interested in how fracking impacts the entire region, not just the immediate county. This is particularly important since substantial new fracking activity occurs in sparsely populated counties. We also examine data aggregated to the state level.

Several conclusions emerge from our analysis. First, the counties where extraction occurs enjoy significant economic benefits. Second, the effects grow larger as we widen the geographic area being examined. The state-level impact on jobs and income is approximately five times as large as the immediate county effect with most of the impact happening within 100 miles of the drilling sites. Third, we find no significant change in crime rates.

Each million dollars of new oil and gas production is associated with a $\$ 66,000$ increase in wage income and 0.78 new jobs within the county. Roughly 40 percent of the income increase is in industries not directly related to oil and gas extraction such as finance, leisure, hospitality, and local government. Of the $\$ 66,000$ increase in local wages, $\$ 39,000$ are wage payments to oil and gas industry workers, including trucking, and another $\$ 27,000$ are wage spillovers to workers in other industries. There are another $\$ 61,000$ in royalty payments to lease holders within the county. The direct effects imply that roughly 10 percent of the total value of gas and oil extracted remains in the county in the form of wages and royalty payments with another 2.7 percent in indirect activity.

Within a 100-mile radius, each million dollars in new production is associated with wage increases of $\$ 243,000$ and 2.49 jobs, which are about three times as large as the effects at the county level. We also find regional spillovers for royalty payments: each million dollars generates almost $\$ 117,000$ of royalty payments within a 100-mile radius. Since royalty payments are 12 to 20 percent of the production value, this suggests that the majority of royalty payments remain local. Overall, 
we conclude that 36 percent of the value of new production shows up in households within commuting distance of the drilling locations.

Our results also provide some insight into the aggregate impact of the fracking boom. A significant portion of the increase in oil and gas production occurred during the depths of the Great Recession. With the national economy operating at significantly less than full employment, the increased demand for labor generated by the fracking boom almost certainly increased overall employment. Our employment estimates suggest that an increase of 725,000 jobs were associated with new oil and gas extraction between 2005 and 2012. Assuming no displacement from other employment, this suggests that the fracking boom lowered aggregate US unemployment by 0.5 percent during the Great Recession.

\section{Literature Review}

There is a related and growing literature on whether or not fossil fuels create a resource curse in a region by raising wages in one sector and crowding out other sectors. Jacobsen and Parker (2014) find that the oil bust in the 1980s harmed manufacturing employment more than the boom in the 1970s helped employment in this sector. This is analogous to the Black, McKinnish and Sanders (2005) finding that the coal bust hurt income and employment more than the boom helped.

In contrast, Allcott and Keniston (2014) find that energy extraction benefits, rather than harms, local manufacturing employment by using exposure to national shocks (as measured by proven reserves) as an instrument. Similarly, Weber (2013) does not find evidence of a resource curse and instead finds that non-mining jobs are positively correlated with mining jobs. Michaels (2011) uses data covering a longer time horizon-from 1890 to 1990 -and finds that oil abundant counties in the 
US South saw higher population growth and higher income per capita growth than counties without oil.

Several recent papers have focused on the fracking revolution, but use different empirical strategies from our paper. Weber (2012) examines county-level direct effects of gas production in three states from 1998 to 2008. Other papers have used indirect measures of production. Fetzer (2014) examines the county-level direct effect of any drilling activity after 2007 by instrumenting with the presence of shale. Maniloff and Mastromonaco (2014) study the effect of the number of wells (and a similar instrument) as a measure of production. ${ }^{\text {W }}$ Our paper differs from the literature in several ways: we use detailed measures of production from new wells for all states; we study the effect during the Great Recession; and we examine regional economic spillovers from shocks to this industry.

Our work has implications beyond an understanding of the local effects of oil and gas fracking. We are studying a large and arguably exogenous shock that can teach us about the size and breadth of geographic spillovers from localized economic activity. Our estimates contribute to the literature on the economic responses to local shocks in the spirit of Blanchard and Katz (1992), Black et al. (2005) and Shoag (2015). Black et al. (2005) find that each coal mining job added to a county during the coal boom created an additional 0.17 jobs in other industries. In contrast, we find larger spillovers from fracking at both the county and state level. ${ }^{\text {व }}$

It is worth noting that the increase in drilling activity is not universally viewed as positive. The regions where this activity is taking place tend to be rural and

\footnotetext{
${ }^{1}$ Other papers related to this topic include Bartik, Currie, Greenstone and Knittel (2014), Considine, Watson and Considine (2011), Deller and Schreiber (2013), Marchand (2012), Wang and Krupnick (2013), and Weber (2013).

${ }^{2}$ For example, at the county level, each million dollars of oil extracted results in 0.49 jobs within the natural resources and the transportation categories. But there are an additional 0.31 jobs created in other industries such as construction and leisure. This implies a spillover of 0.6 jobs for every person employed directly in extraction.
} 
drilling activities generate significant local impacts. Newell and Raimi (2015) find significant heterogeneity in the impact on local government finance. Media reports have noted increases in crime and congestion that have accompanied increased economic activity. Many landowners and environmentalists have expressed concern about water contamination, either from fracking fluids leaking into aquifers or surface water contamination from leaks in ponds where fracking water (fluid) is stored. A 2015 draft study by the EPA admits this possibility but finds it to be quite rare. ${ }^{\text {⿴囗 }}$ These concerns have led to many communities questioning whether the local benefits exceed the costs. New York State has placed a moratorium on fracking while several counties in Colorado have done the same.

Several recent papers have examined the environmental concerns with shale gas and oil, including water quantity, water quality, local air pollution, methane leakages, and earthquakes. Howarth, Ingraffea and Engelder (2011) debate many of these concerns and risks. In a recent paper examining people's perceptions of the risks from fracking, Muehlenbachs, Spiller and Timmins (forthcoming) find that homes relying on wells for drinking water have fallen in value because of drilling activity in Pennsylvania. The empirical evidence does find some support for these concerns. For example, Olmstead, Muehlenbachs, Shih, Chu and Krupnick (2013) find increases in chloride concentrations downstream of treatment plants processing shale gas waste and increased concentrations of total suspended solids in watersheds with new shale gas wells.

\footnotetext{
${ }^{3}$ See, For example, see these three New York Times articles: Healy (2013), "As Oil Floods Plains Towns, Crime Pours In"; Galbraith (2012), "In Oil Boom, Housing Shortages and Other Issues"; and Urbina (2011b), "A Tainted Water Well and Concern There May Be More."

${ }^{4} \mathrm{EPA}$ (2015), http://www2.epa.gov/hfstudy/executive-summary-hydraulic-fracturing-studydraft-assessment-2015
} 


\section{Local Geology and the Technology of Fracking}

Domestic oil production has increased every year since 2008, reversing a decline that began in 1986. The Energy Information Administration (EIA) projects that the US will soon exceed the 1970s level of oil production of 11.5 million barrels per day (EIA 2013a). As a result, the US oil and gas industries added about 300,000 jobs from 2004 to 2012. Additionally, fuel prices have responded to this supply shock: domestic natural gas prices fell by two thirds between 2005 and 2012 while global oil prices fell by half in the fall of 2014 . ${ }^{\text {t }}$

Shale gas and oil refer to fossil fuels trapped in shale formations, which are finegrained, sedimentary rocks. While these resources have been known for decades, it was not until the early 2000s that they began to be developed in earnest (EIA 2013b). Wang and Krupnick (2013) point to several culminating events that lead to the shale revolution starting in the mid-2000s. Industry combined the use of several technological innovations in horizontal drilling, hydrofracturing, and three-dimensional seismic imaging. ${ }^{\text {Th }}$ High natural gas prices enabled some firms to risk experimenting with the new technique. Finally, favorable conditions exist in many locations throughout the United States: conditions include geology, property rights, market

\footnotetext{
${ }^{5}$ Employment in the natural resources and mining sector grew from 1.68 million in 2004 to 1.98 million in 2012 (BLS Quarterly Census of Employment and Wages). Similar changes are reported in the BLS Current Employment Statistics for mining category, 509,000 to 800,000 over this time period.

${ }^{6}$ Gas prices fell from $\$ 10$ per million British Thermal Units (MMBTU) in October 2005 to $\$ 3.35$ by the end of 2012 (see http://www.eia.gov/dnav/ng/hist/n.91.90us.3m.htm). The oil price drop occurs after our sample period and was due to a number of factors in addition to US crude supply. Below, we examine whether there are asymmetric responses to prices rising or falling.

${ }^{7}$ The process of developing shale gas and oil begins with geological surveying. New seismic imaging technology allows geologist to better understand the structure and properties of the subsurface rocks (Bohi 1999). After permitting, a firm will develop a multi-well pad. From one location, the company can drill eight horizontal wells and access the same reservoir volume as sixteen vertical wells (DOE 2009). Casing and cement is installed to protect against leaks. Wells are typically drilled thousands of feet below groundwater and then turn horizontal thousands of feet more. Next, a firm will begin hydraulic fracturing by injecting high-pressure fracture fluid mix of water, sand and chemicals into the well bore. This causes cracks and fractures to develop and the hydrocarbon to be extracted.
} 
structure, pipeline infrastructure, and water availability. Joskow (2013) discusses the importance of deregulation in the recent developments in the gas industry.

Over the past decade, the share of US petroleum production coming from shale resources has increased dramatically. Figure 1 shows oil and gas production separately for vertically and horizontally drilling fuels. In 2000, the amount of fuel produced from vertically drilled wells greatly exceeded that from horizontal wells. By 2013, this pattern has reversed and aggregate production has increased dramatically. This trend is not expected to end soon (EIA 2013a). EIA estimates that the United States has 223 billion barrels of shale oil and 2,431 trillion cubic feet of shale natural gas, over a third of the world's recoverable shale resources (EIA 2013b). The locations of this activity is geographically specific. For each county, Figure 2 shows the cumulative value of new fossil fuel extraction per capita between 2004 and 2012 .

\section{Data Description}

For our analysis we combine sectoral level data on income and employment from the BLS, income data from the IRS, and data on oil and natural gas production from the energy information service Drillinginfo.

From the BLS, we use the Quarterly Census of Employment and Wages, which has information on annual average employment and wages by county. These data come from employers and therefore are our best measure of county-level economic activity. These data are disaggregated into the following sectors: natural resources and mining; trade, transportation and utilities; construction; leisure and hospitality; financial activities; local government; education and health services; information; manufacturing; professional and business services; and state and federal government. 
Figure 1: Production By Drill Type

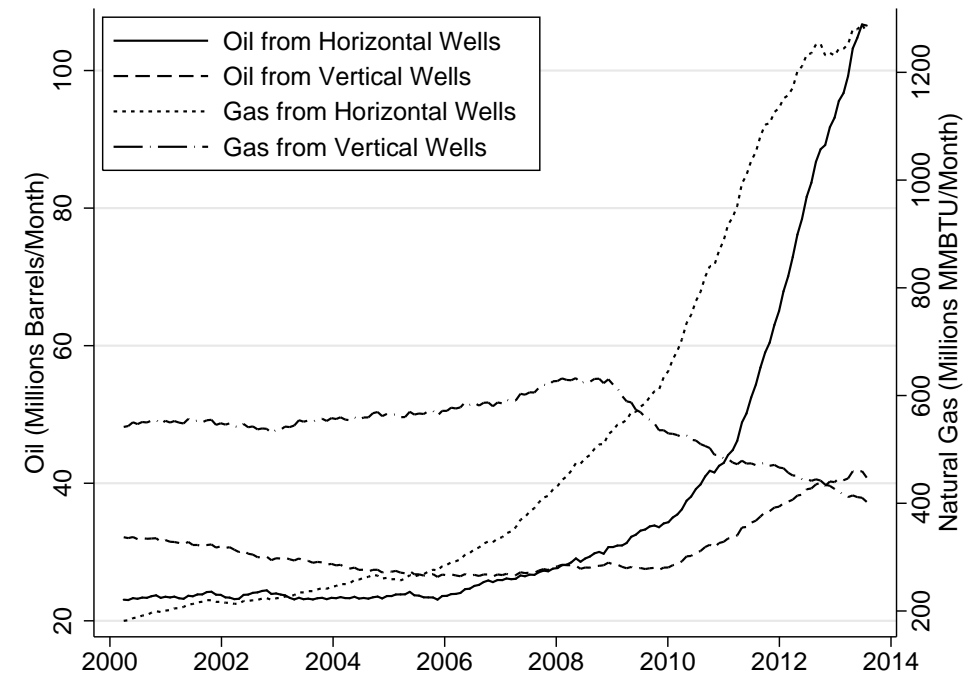

Notes: We report aggregate barrels of oil produced in a given month from wells with a drilling type of vertical or horizontal (including directional). These totals differ from other national reports as we exclude wells with unknown drilling types. There are 5.6 MMBTU per barrel of crude oil. Data source is drillinginfo.com.

Figure 2: New Production from Fracking

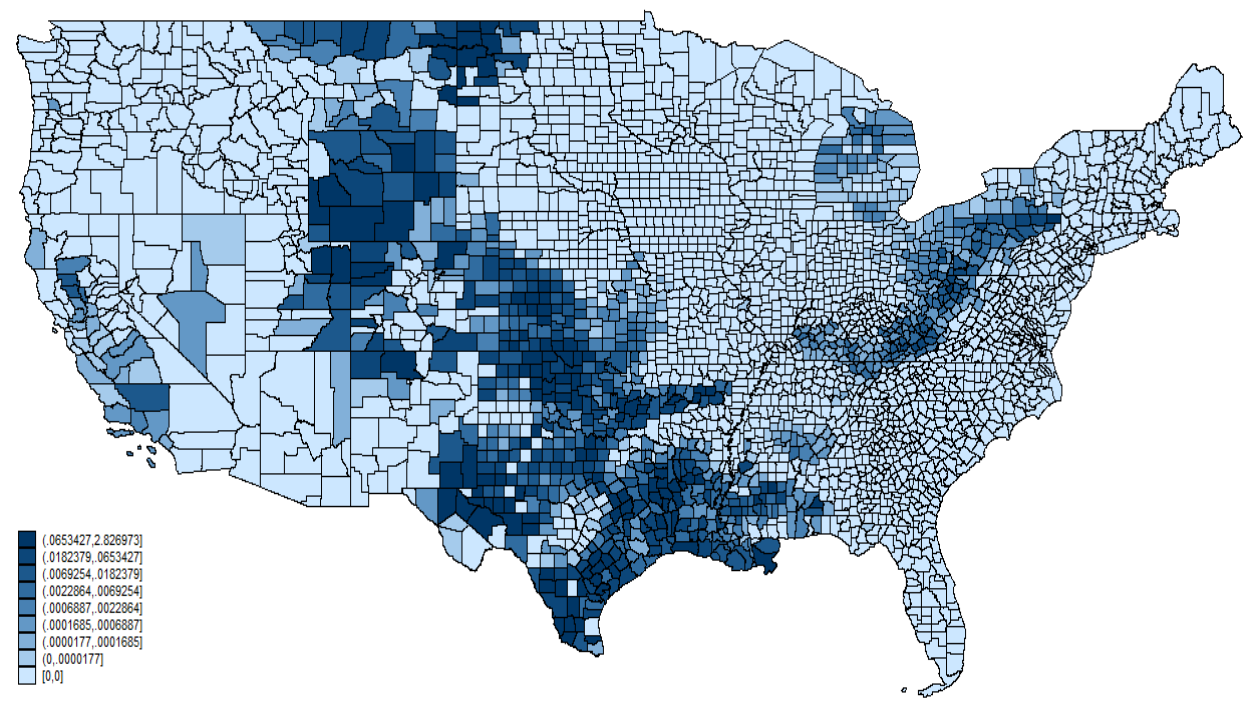

Notes: This figure plots each county's cumulative value of new production per capita from 2004 to 2012. Data sources are drillinginfo.com and BLS. 
These disaggregated data allow us to see if the income and employment effects are restricted to sectors that are directly employed in oil and gas extraction (mining and transportation) or whether these effects are seen in other sectors.

The IRS Statistics of Income data have county-level information on annual wages, dividends, interest and other income. These data are likely to be less useful than the BLS data for county-level estimation because the data are assigned to the county where the tax form is filed by the individual rather than the location of economic activity. For workers that are commuting, or for those that have temporarily relocated for a job, the location where they file taxes may be different from the location where they actually perform the work and collect paychecks. These data are potentially useful in another way. The IRS data are broken into three categories: wages; interest and dividends; and other income. ${ }^{\text {. }}$ We are particularly interested in the other income category because this is where royalties to land holders should appear. These royalties can be 12 to 20 percent of the value of production (Urbina 2011a).

The crime data are from the Uniform Crime Reporting Statistics of the Department of Justice. The UCR Program collects statistics on violent crime (murder and non-negligent manslaughter, forcible rape, robbery, and aggravated assault) and property crime (burglary, larceny-theft, and motor vehicle theft) from local agencies.

Drillinginfo collects oil and natural gas drilling information from various state agencies for each well and month. We use fuel prices from the EIA to determine values. ${ }^{\text {W. }}$ We have BLS and Drillinginfo data from 2004 to 2014. However, the IRS

\footnotetext{
${ }^{8}$ Results on the interest and dividends portion of the IRS income were always insignificant and are not reported.

${ }^{9}$ These data are available at ht.t.p://www. ucrdatatool.gov/ and ht.t. : //doi.org/10.3886/ ICPSR35019.v1

${ }^{10}$ We use the West Texas Intermediate monthly spot oil price (ht.tp://www.eia.gov/dnav/pet// pet_pri_spt_s1_m.htm) and the U.S. natural gas monthly wellhead price (http://www.eia.gov/ dnav/ng/hist/n9190us3m.htm).
} 
data are available with more of a lag, so we focus on 2004 to 2012 when we have all data for all variables. All values are converted to 2014 dollars using the CPI.

Drillinginfo has information on over one million wells that were active during our sample. We define oil wells as those wells with a well type classification of Oil or O\&G, and gas wells as those classified as Gas. We focus only on wells that begin producing oil or gas in a given year. New oil wells account for nine percent of the oil produced in the US during our sample. New gas wells account for 13 percent of natural gas. We aggregate these data by county and year.

Our identification strategy relies on changes in production and changes in outcomes and hence identification derives from the states and counties that are the major producers of each fuel. The most active counties producing oil are in California, Colorado, Kansas, Louisiana, New Mexico, North Dakota, Ohio, Oklahoma, and Texas. The most active gas-producing counties are in Arkansas, Colorado, Louisiana, New Mexico, Pennsylvania, Utah, Texas, West Virginia, and Wyoming. From 2005 to 2012 , the new production in our sample is valued at $\$ 81$ billion in oil and $\$ 136$ billion in gas.

Our county-level analysis includes all US counties with employment of more than 446 people in 2004, at the beginning of our sample. The 63 excluded counties represent 15 states and are the smallest two percent by employment. We exclude these counties because there are a few with very small populations and significant new production of oil and natural gas. Our analysis examines the value extracted per capita: therefore, the results are sensitive to the inclusion of these counties. To take one extreme example, Loving County Texas has over $\$ 10$ million in new oil per capita in one year with about 50 workers. For the sake of consistency, we exclude all counties below a size threshold that excludes these outliers. The new production in these counties is included in all the rest of our analysis including the state-level 
results, the distance results, and the county-size results.

Our sample consists of eight years, 3,082 counties, and 24,646 county-year observations for each industry. Well data are missing for a few observations, making the sample an unbalanced panel. The sample exhibits substantial variation in countylevel employment, with a coefficient of variation over three. For this reason, we normalize all variables by historic employment, which we proxy for using the oneyear lag of total employment.

We construct instruments using data on the presence of shale in a region (i.e. plays) from the EIA. We assign each county to a specific play. Small plays with less than ten counties are combined into a single "other" category, resulting in 23 designations of plays such as the Utica, Marcellus, Devonian, Antrim, New Albany, Barnett, and Bakken shale plays.

\section{Empirical Framework}

Our estimating equation examines the percentage change in total wages. The dependent variable $\Delta W$ ages $_{i t}$ is the one-year change in annual wage payments across all industries divided by the one-year lag of average employment.

The key independent variable is the total value of oil and natural gas extracted from wells that started producing in the current year measured in million dollars per capita, NewValue $i t$. New production is the variable of interest because it represents a potentially exogenous shock to local economic activity. New production is a function of preexisting geology and the newly introduced technology of horizontal drilling combined with fracking. These should be independent of other shocks oc-

\footnotetext{
${ }^{11}$ All references to per capita data in the paper are referenced to average employment levels.

${ }^{12}$ Given the large variation in county populations (levels of employment), we obtain similar but noisier estimates if we instead regress annual changes of the level of employment on the level of fossil fuel production.
} 
curring within the county. Ideally these shocks should occur independent of other county characteristics. In the Appendix, Table A] shows that the areas with fracking are historically similar to other areas based on 2004 population, income, and wage rates. This also shows that early adopting counties are similar to late adopting counties.

We control for county fixed effects, $\alpha_{i}$, and year fixed effects, $\omega_{t}$. Standard errors are clustered by state-year in order to control for spacial correlation. ${ }^{\mathbb{1 3}}$ For county $i$ in year $t$, we estimate:

$$
\Delta \text { Wages }_{i t}=\beta * \text { NewValue }_{i t}+\alpha_{i}+\omega_{t}+\epsilon_{i t}
$$

\subsection{Spatial Propagation}

County-level analysis of the BLS data only includes employment that firms report as being located in the county where the fracking activity is occurring. To the extent that drillers are transient workers who are reported as being employed by establishments in a different county (e.g. the company headquarters), county-level results will understate the impact of new oil and gas production. In addition to the reporting problem workers may not live and shop in the counties where the new extraction is taking place. This will result in spillover economic activity in neighboring counties that will not be picked up in the county-level analysis.

Examining data aggregated at the state level will deal with both of these issues. Firms are required to pay unemployment insurance premiums in the state where the worker is located so state level aggregates should accurately reflect the location of work. States are not the ideal level of aggregation because they vary widely in

\footnotetext{
${ }^{13}$ Clustering at the county level, which will better deal with serial correlation, does not significantly change any of our results.
} 
size and many states contain multiple economic areas.

We further extend our county-level analysis to include new production in surrounding counties. We sum the value of new production and the change in income with a 100 miles radius of the centroid of a county and divide it by the the population living within the 100 mile radius to generate new production and income per capita. We estimate equation (耳) on these summed values for each county. By performing a similar analysis at different distances we can analyze the geographic propagation of income and employment as we get farther from the source of the new production.

\subsection{Instrumental Variables}

Our new production measure will be a function of the availability of the new resource and the actions taken to extract it. While the former is clearly exogenous, the latter may not be. It could be that some areas are fracked earlier because the cost of gaining leases is low due to low land values or because wages are low due to high unemployment. For this reason we will instrument for new production in each county using geological formations.

Our main approach is to use the time series of productivity in geological regions (a play) to predict county-level production. We generate predictions for aggregate new production in each county for each year by estimating:

$$
\ln \left(\text { NewValue }_{i t}\right)=\alpha_{i}+\lambda_{j t}+\epsilon_{i t}
$$

where $\alpha_{i}$ is a dummy for each county and $\lambda_{j t}$ represents a set of dummy variables for each play-year combination. We can then generate a prediction for new production 
per capita for each county year pair:

$$
\text { New } \hat{\text { alue }} e_{i t}=e^{\hat{\hat{\alpha}_{i}+\lambda_{j t}}} / \text { pop }_{i t}
$$

The predicted values for new production per capita are based on the timing of new production for all the counties within a particular play. Each individual county represents a small part of the play's production so that the instrument is exogenous with respect to the idiosyncratic rollout of fracking within individual counties. We end up with 23 plays with some counties in multiple plays. On average each play contains 32 counties.

These predicted values will be used as instruments in an IV regression where new production is instrumented using our predicted values. We are using this two step process to generate instruments because the functional form for predicting new production is very different than the functional form when we specify the regression. We will focus on new production per person in our estimations because we are interested in how new production impacts communities. The availability of new production is geographic and orthogonal to the presence of people. A log specification for generating predicted values allows us to include a multiplicative dummy for each county. The predicted values for each county will incorporate the timing of new production from the play dummies while controlling for the idiosyncratic level of production in each county. Since we are getting all of our identification in the second stage from the timing of new production our instruments will be valid. 


\section{Income and Employment Results}

Table 1 shows the results of estimating equation (1) for aggregate wages from the BLS, and adjusted gross income (AGI), wages, and other income from the IRS. Each entry in the table represents the coefficient from a different regression. The OLS estimates suggest that one million dollars of new oil and gas production in associated with a BLS wage increase of $\$ 35,000$ within the county. The impact increases substantially when we expand the geographic area of interest. At a 100 mile radius from the county centroid each million dollars of new production per capita is associated with wage increases of $\$ 214,000$. Aggregated to the state level this increases to $\$ 287,000$.

As described in the previous section, the OLS results may be biased because the choice of counties for drilling may be non-random. We deal with this potential endogeneity by generating instruments based on the potential for fracking within a particular county based on the geology of the region. For the remainder of the paper we will confine our discussion to IV estimation while continuing to report OLS results in the tables.

Panel B of Table 10 reports our IV results. ${ }^{\text {प] }}$ These estimates suggest that one million dollars of new oil and gas production in associated with a BLS wage increase of $\$ 66,000$ within the county. This increases substantially as we look more regionally. At a 100 mile radius from the county centroid each million dollars of new production is associated with wage increases of $\$ 243,000$. Aggregated to the state level this increases to $\$ 343,000$.

Results using IRS data suggest smaller wage effects, with one million of new production associated with $\$ 27,000$ in increased wages at the county level, $\$ 84,000$

\footnotetext{
${ }^{14}$ The first-stage results are reported in Table A2. Separate estimates are reported for oil values, natural gas values, and the combined values. All F-stats are greater than 10.
} 
within a 100 mile radius, and $\$ 171,000$ at the state level. These point estimates are one half to one third of the corresponding BLS wage results. We will tend to rely on the BLS wage data when available because the BLS data reflect the county where the firm is located, not where taxes are filed. We feel that this more reliably captures the geographic dispersion of wages from new production and is therefore measured with less error than the IRS data. This measurement error is attenuating our coefficients toward zero in the IRS income results.

The main advantage of using the IRS data is that the IRS Income measures capture the income from royalty payments that is unavailable from the BLS. We define IRS Other Income to be the difference between AGI and the sum of wages and salaries, dividends, interest, and capital gains. This is an imperfect measure of royalty income since it also includes business income and partnership income. However since we are using changes in the this category for counties with a great deal of new oil and gas extraction, the change in the royalty component is likely to dominate the change in non-royalty income. If anything we risk overstating the effects of new oil and gas production on royalties since new production in a county will also raise business income. ${ }^{\text {.15 }}$

Our results suggest that one million dollars of new production leads to $\$ 61,000$ at the county level and $\$ 117,000$ at the 100 mile level. At the state level, our coefficients for IRS other are extremely noisy with insignificant point estimates. Combining the BLS wage results with the IRS Other estimates from royalty payments we find that almost 16 percent of the value of new production remains in the county of production and 36 percent stays within a 100 mile radius.

\footnotetext{
${ }^{15}$ Regressions on dividends, interest, and capital gains show no significant relationship with new oil and gas production and are therefore not included in our tables.
} 


\subsection{Geographic Dispersion of Income}

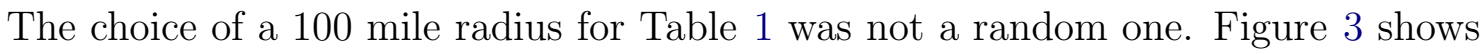
the results of a series of regressions of county-level income changes against the value of new production within a radius of the centroid of the county. ${ }^{[6]}$ As the distance is increased, production from other counties is included in the analysis including production occurring in other states. The coefficients at zero represent the impact of production located within the county (these coefficients are identical to the values reported in Table $\mathbb{1}$ ). Between zero and 50 miles very little new production is being added. As we move from 50 to 100 miles production in adjacent counties is taken into account and the coefficients rise. From 100 to 200 miles the coefficient on Wages flattens while the coefficient on IRS Other Income continues to rise modestly. This distance pattern is consistent with a commuting zone of 100 miles being the most appropriate unit of observation. The continued rise of IRS Other income past 100 miles may indicate that land ownership is more geographically dispersed than employment though we cannot reject that the impact at 100 miles is the same as at 200 miles.

Splitting the results by county size provides additional evidence on the propagation of shocks in Table A3]. We bin counties into 10 equally-sized deciles by initial employment and estimate the main coefficient separately for each. Counties with over 8,000 workers see significantly larger effects of new production that are statistically similar to the state results. This suggests that counties with larger populations are more likely to see the employment gains remain within the county while smaller counties will draw on surrounding counties for workers.

\footnotetext{
${ }^{16}$ This figure reports instrumental variables results. OLS results are reported in Figure A1.
} 
Figure 3: Wage Income (BLS) and Other Income (IRS) Effects Including Neighbors within a Given Distance (IV)

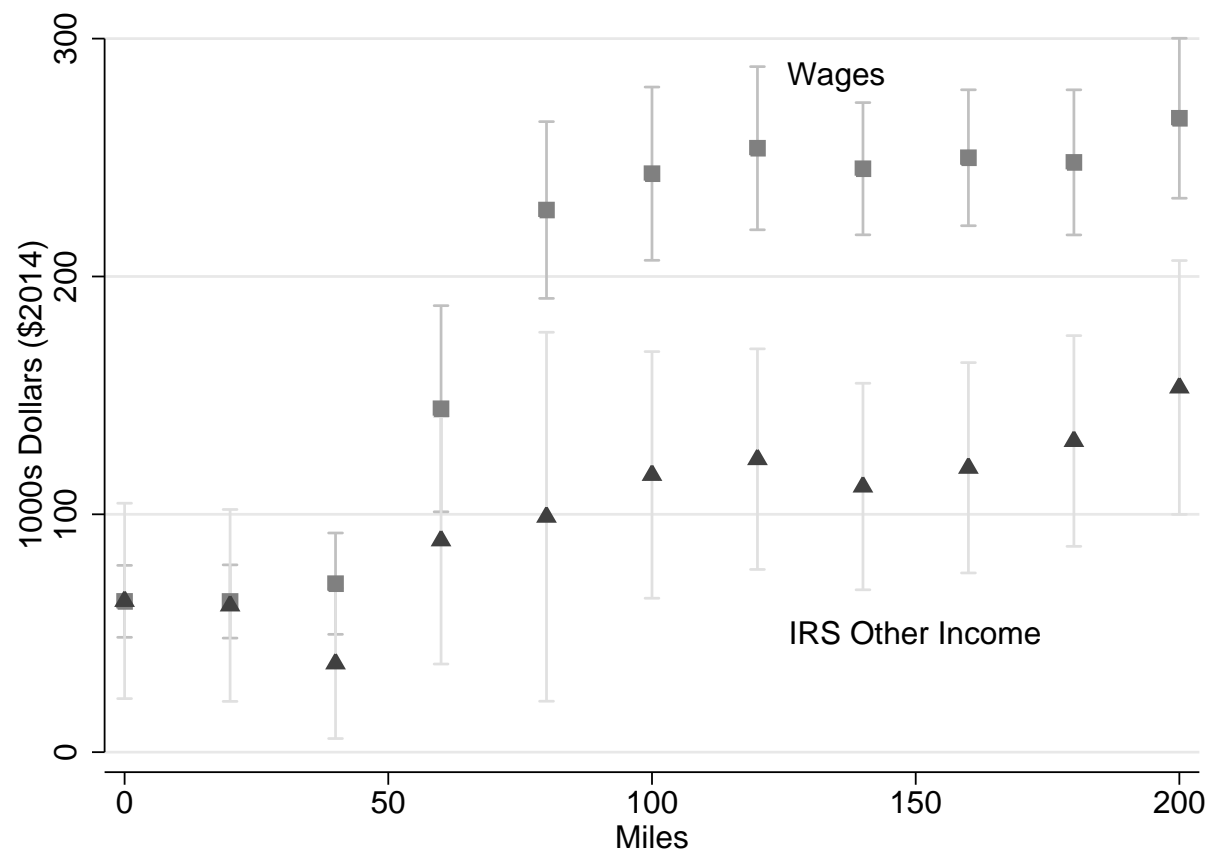

Notes: We estimate the aggregate one-year change in annual income per capita for circles of various radii. We include all counties for whom the distance between the centroids of the originating county and each other county is within a given distance. Using two stage least squares, we regress this measure on the aggregated total value (in millions of dollars) from wells opened in the current year per capita within the corresponding circle. See text for discussion of the instrument. We control for county and year fixed effects. The figure reports the coefficient estimates and the 95 percent confidence interval where the standard errors are clustered by state-year. 


\subsection{Industry-Level Income}

Table 2 breaks down the BLS income results by industry. We will focus on the IV results in Panel B. As in the previous section we find that one million dollars of new production is associated with $\$ 66,000$ of additional wages at the county level. In Table $\square$ we see that $\$ 24,000$ occurs in mining, and $\$ 16,000$ in trade and transportation. Added together, roughly two thirds of the income is in sectors that are directly involved in extracting new gas and oil. Of the remainder, the largest impact is in construction.

At higher levels of aggregation the story is quite similar. Each million dollars of new production is associated with $\$ 243,000$ at the 100 mile level with $\$ 105,000$ in mining and $\$ 63,000$ in transportation. At the state level wages increase $\$ 343,000$ overall with $\$ 120,000$ in mining and $\$ 75,000$ in transportation. In all three cases roughly two thirds of the wage increases occur in sectors directly related to extraction.

\section{Employment}

We find similar patterns in employment. Table 1 reports the results of regressions using BLS employment by industry. Each million dollars of additional oil or gas production generates an employment increase of 0.78 at the county level. Of this, 0.28 is in mining and 0.21 in transportation. At the 100 mile level we find an employment increase of 2.49 with 0.95 in mining and 0.73 in transportation. At the state level we find an employment increase of 3.34 with 1.21 in mining and 0.91 in transportation. As with the income results, we find that about two thirds of the increase is in mining and transportation. Of the remaining one third construction plays the largest role followed by leisure. 
Figure 14 shows the results of a series of regressions of county-level employment changes against the value of new production within a radius of the centroid of the county. Mirroring the income results, employment effects are much larger as one considers effects beyond the immediate county. The employment effects reach a maximum at 100 miles suggesting that the commuting radius is the correct unit of observation, not the county.

The impact of new production within a 100 mile radius are over three times as large as with the county and quite similar to the impact at the state. This suggests that our state results are driven by impacts outside the immediate county, but still within the region where new production is located. Counties within the shale regions are therefore seeing overall employment and wage effects that are substantially larger than suggested by the county-level results and closer to the state results.

The income and employment effects are extremely similar and are consistent with each new job in a county paying roughly $\$ 100,000$. We cannot, however say with certainty whether this is the correct interpretation. It seems likely that the increased activity led to a combination of new jobs along with higher wages for existing jobs within the county and region. We cannot distinguish between these two effects.

\section{Robustness}

\subsection{Wells versus Production}

Our preferred specifications use the per capita change in the value of oil and gas production on the right hand side. There are several alternative measures of fracking activity that were also considered. The increase in production value is a combination of new wells drilled, the average production of each new well, and the price of oil and 
Figure 4: Employment Effects Including Neighbors within a Given Distance

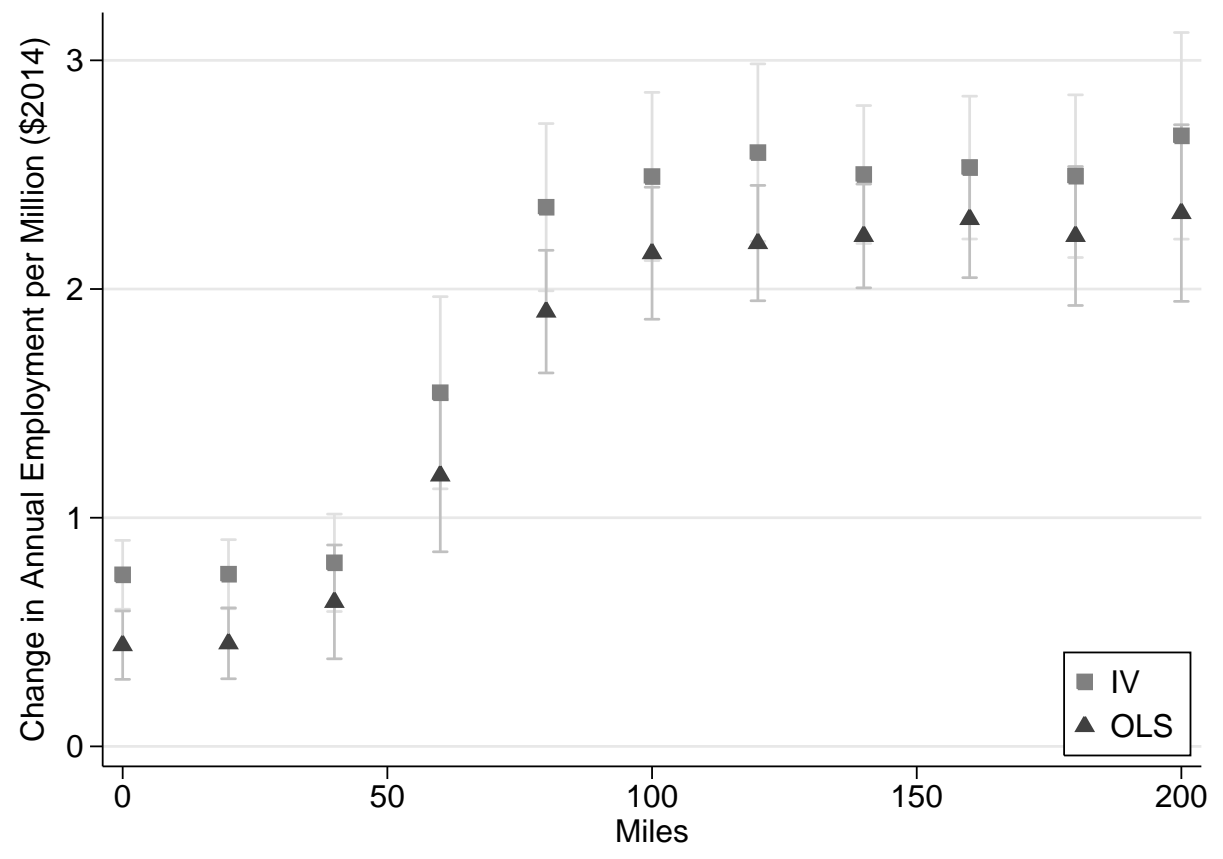

Notes: We estimate the aggregate one-year change in annual employment per capita for circles of various radii. We include all counties for whom the distance between the centroids of the originating county and each other county is within a given distance. We regress this measure on the aggregated total value (in millions of dollars) from wells opened in the current year per capita within the corresponding circle. We control for county and year fixed effects. The figure reports the coefficient estimates and the 95 percent confidence interval where the standard errors are clustered by state-year. 
gas during the production period. Because we include time effects in all regressions, changes in oil and gas prices play a minor role.

In Table A4, we consider whether the number of new wells has predictive power independent of production because the process suggests a fixed labor cost to creating a well regardless of the wells productivity. This did not turn out to be the case. In regressions including both the value of production and well data, we find that production data have greater predictive power. Part of the explanation may be that productive wells are re-fracked more often and involve more trucking and more extensive horizontal drilling. It may also be that the willingness to invest in new wells is proportional to the expected production from these wells, leading to a strong correlation between the costs of opening a well and the value of new production. Because the well and production data are highly correlated with each other it is not possible to separate out the effects.

\subsection{Oil versus Gas}

It is possible that new oil drilling and new gas drilling have different impacts. The point estimates when we estimate new oil extraction and new gas production separately suggest that oil has a larger impact on wages than natural gas $(\$ 260,000$ in wages per million for oil production versus $\$ 180,000$ for gas production for our preferred specification of county plus 100 miles using instrumental variables), but that these differences are not statistically significant (Table A.5).

Figure A2 shows the results split by oil and gas at varying distances from the county centroid. Between 0 and 100 miles the impact of natural gas and oil are very similar. The impact of oil flattens out at distances larger than 100 miles while natural gas continues to have marginal effect out to 200 miles, though the standard errors are quite large. 


\subsection{Rising versus Falling Fossil Fuel Prices}

Oil prices have played a role in the timing of the fracking boom, with high prices between 2005 and 2008, followed by a collapse during the Great Recession. We may worry that our results are being driven by periods of high oil prices in ways not captured by time dummies. We therefore split our sample by periods of rising and falling prices. Oil and natural gas prices generally move together, but there are a few periods where they diverge. We therefore split the sample based on whether a county sees rising or falling prices for the dominant fuel in that county. Both the rising and falling price samples include all the non-producing counties as a control group. Table A6 shows our main results for each of these samples. The results do not seem to be affected by the direction of prices.

\subsection{More Recent Data}

Our analysis has focused on the period 2005-2012 due to availability of the IRS data. The BLS data is available through 2014. Tables $A 7$ and $A 8$ presents our results for this extended sample using the BLS data. Adding these additional data reduces the magnitude of all of our coefficients somewhat with about a twenty percent reduction in our preferred IV specification. All coefficients remain highly significant.

In order to explore this further we split the sample into three periods. The first period, 2005 to 2008 , includes the early years of the fracking boom but does not include the Great Recession. The second period, 2009 to 2011 is during the Great Recession and ends with our IRS sample. For the final period, 2012 to 2014, we only have BLS data. This is a period with falling unemployment and a more mature fracking industry. Table A.9 present the results across these three time periods. The first and second periods are very similar to each other though it is clear that the 
period during the Great Recession is providing a lot of the identification. This suggests that our results are not being driven by the labor market weakness of the recession. The results from the period 2012 to 2014 are extremely noisy.

\section{Crime}

A major concern with the fracking boom is the local impact on crime. Several New York Times articles have discussed large crime increases in North Dakota and Montana towns. ${ }^{\square 7}$ In Table 4 , we examine the impact of new production on crime at the county level. Our OLS results show no significant increase in crime in any category. For the IV results, the coefficient on murder is significant at the 10 percent level. Given that we find only one coefficient that is weakly statistically significant in a table of 16 coefficients, we do not consider our results to be evidence of crime increases as a result of fracking.

These news articles focus solely on the top five to ten counties as ranked by new production per capita. In our data, the six counties in the top one percent of oil drilling activity have over $\$ 750,000$ of new production per capita during our sample period. Our point estimate multiplied by production at the 99th percentile suggests a violent crime rate increase of 40 percent with a 95 percent confidence interval of -186 percent to +265 percent, and a 12 percent decrease in property crime with a 95 percent confidence interval of -122 percent to 98 percent. While these estimates do not preclude the possibility of large increases in crime in some counties as a result of new drilling activity, our analysis cannot reject relatively small increases in crime for even the largest oil producing counties.

\footnotetext{
${ }^{17}$ For example, crime has been written about Dickinson and Watford City, ND (Healy 2013).
} 


\section{Discussion}

What does this mean for the typical county that has fracking activity? This question is complicated by the extremely skewed distribution of production within the counties where fracking is taking place. There are 739 counties in the US that had either new oil or gas production in the first year of our sample, 2005. The median county in this group had $\$ 4,900$ of new production per capita over the sample period. Our results imply a 0.38 percent increase in employment and a $\$ 320$ increase in wages per capita. Counties at the 75 th percentile in new production have over five times the production of the median at $\$ 25,900$ per capita. Our results suggest a 2.00 percent increase in employment and a $\$ 1,700$ increase in wages per capita in these 140 counties. The top five percent of counties (about 37 counties) saw production increases in excess of $\$ 290,000$ per capita associated with a 23 percent increase in employment and a $\$ 19,000$ increase in wages per capita.

This analysis only considers the direct impact on the county. Our results suggest that including the surrounding counties increases the impact by a factor of more than three. To put this in perspective we can consider a hypothetical state with 500,000 workers. The state contains one centrally located county of 10,000 workers that extracts one million dollars of new oil and gas per capita. ${ }^{\text {[8 }}$ Roughly one quarter of the oil and gas rights are held by county residents with the other three quarters held by other residents of the state living within a 100 mile radius.

After fracking, employment in our county rises by 78 percent to 17,800 . County income from employment rises by 88 percent. Additionally, each of the incumbent workers receives an average of $\$ 38,000$ in royalty payments. At the state level, employment rises by 33,400, a 7 percent increase. ${ }^{[9]}$ The state unemployment rate

\footnotetext{
${ }^{18}$ Our hypothetical state is roughly based on production figures from North Dakota.

${ }^{19}$ Coefficients for employment and income for the state level analysis are taken from the IV
} 
falls. Aggregate state wage income rises by 20 percent. Additionally, each of the incumbent workers receives an average of $\$ 2,300$ in royalty payments.

Given that the counties where fracking is taking place are geographically clustered, the propagation of shocks over 100 miles suggests that the overall impact on fracking counties is larger than would be expected if their production was taken in isolation because they also benefit from production in the surrounding counties. This may be particularly relevant when discussing fracking bans that affect entire regions, like in New York State.

Aggregating to the national level, we find $\$ 217$ billion worth of new production over our sample period. In mining, our state level IV coefficient of 1.21 suggests 262,000 new mining jobs. Over the same period there was an increase of about 300,000 jobs in mining and natural resources nationally. Our results can therefore account for most of the US employment gain in the mining sector. We cannot reject that the entire increase in mining is due to the new production in our sample. Multiplying this by our overall (all industries) state level jobs coefficient of 3.34 suggests that 725,000 new jobs were created across the nation due to the new production. Given a labor force of approximately 150 million in the US this suggests a 0.5 percent increase in US aggregate employment due to new production of oil and natural gas from 2005-2012, with an identical reduction of the US unemployment rate.

\section{Conclusion}

Our analysis is among the first comprehensive examinations of the effects of fracking on income, employment, and crime. Fracking is particularly interesting because we know the exact location of the wells and are able to measure the impacts at ever

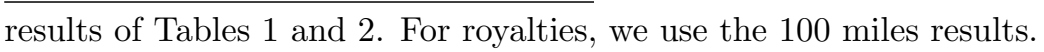


Figure 5: Revenue Decomposition by Distance

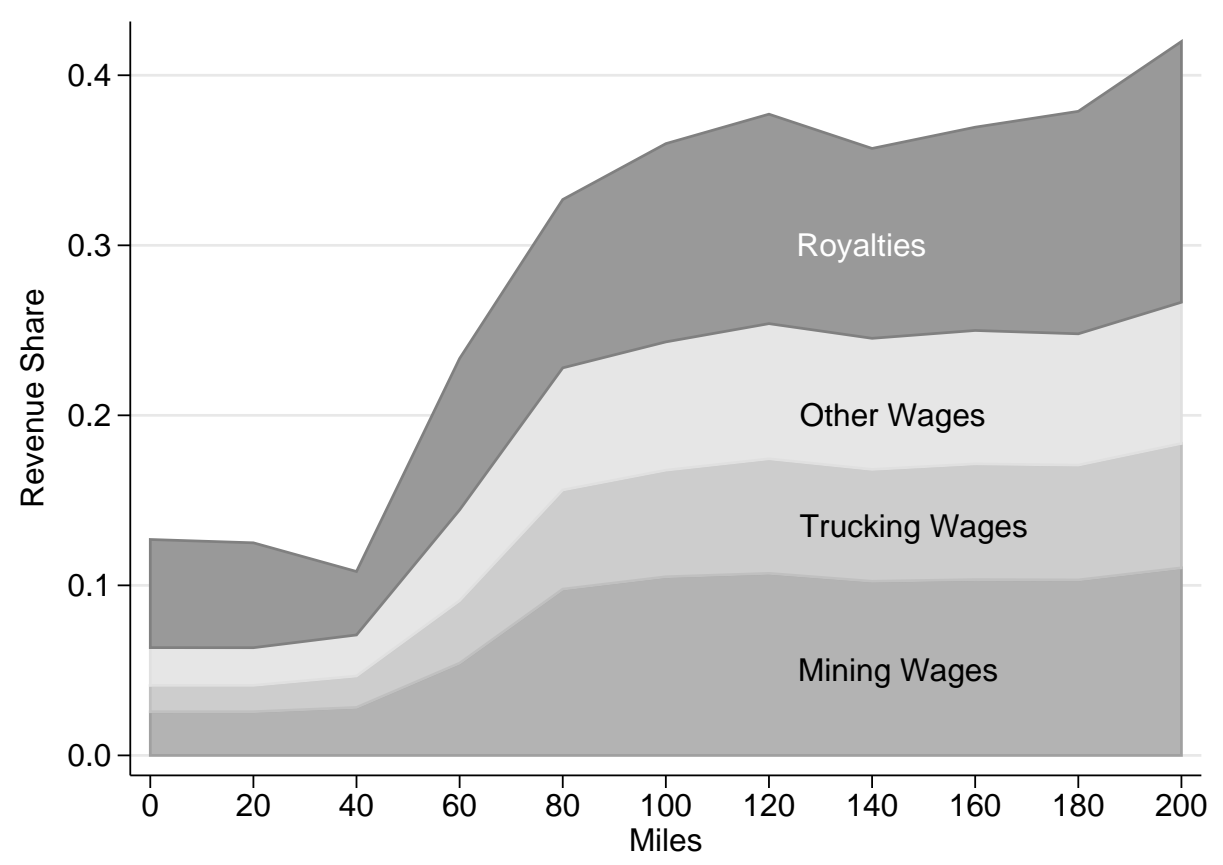

widening levels of geography. New production in our data is being driven by new drilling technology interacted with the preexistence of appropriate geography. Our new production is therefore exogenous to economic conditions at the time of the new drilling. This allows us to study how income shocks propagate through local and regional economies.

Figure 5 summarizes our results. At the county level (at 0 miles distance) our estimates suggest that roughly 13 percent of the value extracted stays in the county in the form of higher income. Wages and royalty payments each account for about half of the increase. Two thirds of the increased wages is in the mining and trucking industries, with the remainder spilling over to construction, hospitality, banking, and local government.

While county impacts are substantial, the regional effects are several times larger. As we move out to 100 miles 36 percent of the new value extracted remains within 
the region. Two thirds of the income increase is in the form of higher wares and one third as royalties. Mining accounts for 40 percent of the wage increase, trucking 25 percent, with the remainder in other industries.

We find substantial increases in regional employment due to fracking. Each million dollar of new production generates an increase in employment of 0.78 workers at the county level, 2.49 within 100 miles, and 3.34 within the state. Aggregating nationally we can explain all of the observed 300,000 increase in mining and oil employment over our sample. Aggregating to the national level we conclude that aggregate employment rose by 725,000 jobs due to fracking, causing a reduction in the US unemployment rate of 0.5 percent during the Great Recession. This almost certainly understates the impact as it only takes into account the direct impact of the value of new extraction. For much of the nation the main impact of the fracking boom was lower natural gas prices which do not play a role in our analysis. 


\section{References}

Allcott, Hunt and Daniel Keniston, "Dutch disease or agglomeration? The local economic effects of natural resource booms in modern America," NBER Working Paper 20508, 2014.

Bartik, Alexander W., Janet Currie, Michael Greenstone, and Christopher R. Knittel, "The Economic Consequences of Hydraulic Fracturing," Presentation, 2014.

Black, Dan, Terra McKinnish, and Seth Sanders, "The economic impact of the coal boom and bust," The Economic Journal, 2005, 115 (503), 449-476.

Blanchard, Olivier Jean and Lawrence F. Katz, "Regional evolutions," Brookings Papers on Economic Activity, 1992, 1 (1992), 1-61.

Bohi, Douglas R, "Technological improvement in petroleum exploration and development," Productivity in Natural Resource Industries. RD Simpson. Washington, DC, Resources for the Future, 1999, pp. 73-108.

Considine, Timothy J, Robert W Watson, and Nicholas B Considine, "The economic opportunities of shale energy development," The Manhattan Institute, June, 2011.

Deller, Steven and Andrew Schreiber, "Mining and community economic growth," The Review of Regional Studies, 2013, 42 (2), 121-141.

DOE, Ground Water Protection Council, Modern shale gas development in the United States: A primer, US Department of Energy, Office of Fossil Energy, 2009 .

EIA, US, "Annual Energy Outlook 2013," 2013.

_ _ "Shale Gas Resources: An Assessment of 137 Shale Formations in 41 Countries Outside the United States," 2013.

EPA, "Assessment of the Potential Impacts of Hydraulic Fracturing for Oil and Gas on Drinking Water Resources," 2015.

FBI, US DOJ., "Uniform Crime Reporting Program Data: County-Level Detailed Arrest and Offense Data," 2012.

Fetzer, Thiemo, "Fracking Growth," CEP Discussion Paper, 2014.

Galbraith, K, "In oil boom, housing shortages and other issues," New York Times, July 122012. 
Healy, Jack, "As Oil Floods Plains Towns, Crime Pours In," New York Times, November 302013.

Howarth, Robert W, Anthony Ingraffea, and Terry Engelder, "Natural gas: Should fracking stop?," Nature, 2011, 477 (7364), 271-275.

Jacobsen, Grant D and Dominic P Parker, "The economic aftermath of resource booms: evidence from boomtowns in the american west," Economic Journal, forthcoming 2014.

Joskow, Paul L, "Natural gas: from shortages to abundance in the United States," The American Economic Review, 2013, 103 (3), 338-343.

Maniloff, Peter and Ralph Mastromonaco, "The Local Economic Impacts of Unconventional Shale Development," 2014.

Marchand, Joseph, "Local labor market impacts of energy boom-bust-boom in Western Canada," Journal of Urban Economics, 2012, 71 (1), 165-174.

Michaels, Guy, "The long term consequences of resource based specialisation," The Economic Journal, 2011, 121 (551), 31-57.

Muehlenbachs, Lucija, Elisheba Spiller, and Christopher Timmins, "The housing market impacts of shale gas development," American Economic Review, forthcoming.

Newell, Richard G. and Daniel Raimi, "Shale Public Finance: Local Government Revenues and Costs Associated with Oil and Gas Development," Working Paper 21542, National Bureau of Economic Research September 2015.

Olmstead, Sheila M, Lucija A Muehlenbachs, Jhih-Shyang Shih, Ziyan Chu, and Alan J Krupnick, "Shale gas development impacts on surface water quality in Pennsylvania," Proceedings of the National Academy of Sciences, 2013, 110 (13), 4962-4967.

Shoag, Daniel, "The impact of government spending shocks: Evidence on the multiplier from state pension plan returns," unpublished paper, Harvard University, 2015.

Urbina, Ian, "Drilling Down: Fighting Over Oil and Gas Leases," New York Times, December 12011.

, "A Tainted Water Well and Concern There May Be More," New York Times, August 32011.

Wang, Zhongmin and Alan Krupnick, "US Shale Gas Development: What Led to the Boom?," 2013. 
Weber, Jeremy G, "The effects of a natural gas boom on employment and income in Colorado, Texas, and Wyoming," Energy Economics, 2012, 34 (5), 15801588 .

Weber, Jeremy G., "A decade of natural gas development: The makings of a resource curse?," Resource and Energy Economics, 2013. 
Table 1: Effects of Fracking on Income

Dependent Variable: One-Year Change in Wages and Salaries per Capita Main Independent Variable: Oil and Natural Gas Value (\$Millions) from Wells Opened in Current Year Per Capita

\begin{tabular}{|c|c|c|c|c|}
\hline & $\begin{array}{c}(1) \\
\text { BLS Wages }\end{array}$ & $\begin{array}{c}(2) \\
\text { IRS AGI }\end{array}$ & $\begin{array}{c}(3) \\
\text { IRS Wages }\end{array}$ & $\begin{array}{c}(4) \\
\text { IRS Other Inc }\end{array}$ \\
\hline & \multicolumn{4}{|c|}{ Panel A: OLS } \\
\hline County & $\begin{array}{c}34,965^{* * *} \\
(6,614)\end{array}$ & $\begin{array}{c}49,418^{* * *} \\
(5,585)\end{array}$ & $\begin{array}{c}10,972^{* * *} \\
(2,072)\end{array}$ & $\begin{array}{c}38,276^{* * *} \\
(5,245)\end{array}$ \\
\hline County +100 miles & $\begin{array}{c}214,230^{* * *} \\
(13,513)\end{array}$ & $\begin{array}{c}155,385 * * * \\
(18,896)\end{array}$ & $\begin{array}{c}63,224^{* * *} \\
(7,396)\end{array}$ & $\begin{array}{c}94,611^{* * *} \\
(15,189)\end{array}$ \\
\hline \multirow[t]{2}{*}{ State } & $\begin{array}{c}287,391^{* * *} \\
(17,480)\end{array}$ & $\begin{array}{c}176,707^{*} \\
(99,691)\end{array}$ & $\begin{array}{c}107,833^{* * *} \\
(26,835)\end{array}$ & $\begin{array}{c}82,915 \\
(109,790)\end{array}$ \\
\hline & \multicolumn{4}{|c|}{ Panel B: IV } \\
\hline County & $\begin{array}{c}65,817^{* * *} \\
(7,642)\end{array}$ & $\begin{array}{c}89,623^{* * *} \\
(23,154)\end{array}$ & $\begin{array}{c}27,287^{* * *} \\
(4,163)\end{array}$ & $\begin{array}{c}60,710^{* * *} \\
(19,828)\end{array}$ \\
\hline County +100 miles & $\begin{array}{c}243,210^{* * *} \\
(18,208)\end{array}$ & $\begin{array}{c}197,221^{* * *} \\
(33,865)\end{array}$ & $\begin{array}{c}83,689^{* * *} \\
(11,237)\end{array}$ & $\begin{array}{c}116,563^{* * *} \\
(25,923)\end{array}$ \\
\hline State & $\begin{array}{c}343,350 * * * \\
(49,008)\end{array}$ & $\begin{array}{c}66,416 \\
(171,527)\end{array}$ & $\begin{array}{c}171,242^{* *} \\
(65,110)\end{array}$ & $\begin{array}{c}-51,017 \\
(194,397)\end{array}$ \\
\hline
\end{tabular}

Notes: Each coefficient represents a separate regression. AGI is adjusted gross income. County +100 miles includes all economic activity from counties within 100 miles radius. Standard errors, clustered by state-year (or state), are in parentheses. There are 24,646 (408) observations in each regression. The county sample excludes counties with 446 or fewer employees in 2004 (2 percent of all counties). 
Table 2: Effects of Fracking on Wages and Salaries by Industry

Dependent Variable: One-Year Change in Wages and Salaries per Capita Main Independent Variable: Oil and Natural Gas Value (\$Millions) from Wells Opened in Current Year Per Capita

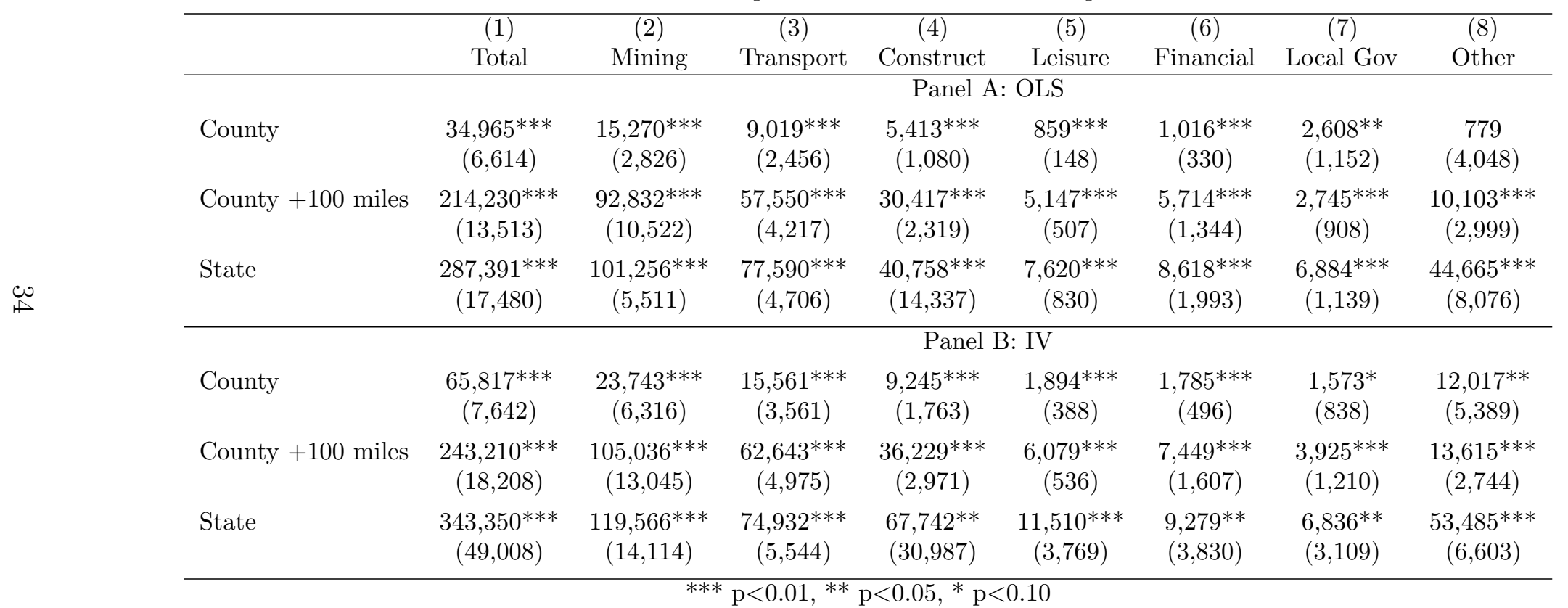

Notes: Each coefficient represents a separate regression. County +100 miles includes all economic activity from counties within 100 miles radius. Standard errors, clustered by state-year (or state), are in parentheses. There are 24,646 (408) observations in each regression. The county sample excludes counties with 446 or fewer employees in 2004 (2 percent of all counties). 
Table 3: Effects of Fracking on Employment by Industry

Dependent Variable: One-Year Change in Employment per Capita Main Independent Variable: Oil and Natural Gas Value (\$Millions) from Wells Opened in Current Year Per Capita

\begin{tabular}{|c|c|c|c|c|c|c|c|c|}
\hline & $\begin{array}{c}(1) \\
\text { Total }\end{array}$ & $\begin{array}{c}(2) \\
\text { Mining }\end{array}$ & $\begin{array}{c}(3) \\
\text { Transport }\end{array}$ & $\begin{array}{c}(4) \\
\text { Construct }\end{array}$ & $\begin{array}{c}(5) \\
\text { Leisure }\end{array}$ & $\begin{array}{c}(6) \\
\text { Financial }\end{array}$ & $\begin{array}{c}(7) \\
\text { Local Gov }\end{array}$ & $\begin{array}{c}(8) \\
\text { Other }\end{array}$ \\
\hline & \multicolumn{8}{|c|}{ Panel A: OLS } \\
\hline County & $\begin{array}{c}0.44^{* * *} \\
(0.07)\end{array}$ & $\begin{array}{c}0.18^{* * *} \\
(0.04)\end{array}$ & $\begin{array}{c}0.12^{* * *} \\
(0.03)\end{array}$ & $\begin{array}{c}0.07^{* * * *} \\
(0.02)\end{array}$ & $\begin{array}{c}0.03^{* * *} \\
(0.01)\end{array}$ & $\begin{array}{c}0.01^{* * *} \\
(0.00)\end{array}$ & $\begin{array}{c}0.05 \\
(0.03)\end{array}$ & $\begin{array}{l}-0.03 \\
(0.06)\end{array}$ \\
\hline County +100 miles & $\begin{array}{c}2.16^{* * *} \\
(0.14)\end{array}$ & $\begin{array}{c}0.82^{* * *} \\
(0.10)\end{array}$ & $\begin{array}{c}0.68^{* * *} \\
(0.05)\end{array}$ & $\begin{array}{c}0.36^{* * *} \\
(0.04)\end{array}$ & $\begin{array}{c}0.12^{* * *} \\
(0.02)\end{array}$ & $\begin{array}{c}0.05^{* * *} \\
(0.01)\end{array}$ & $\begin{array}{l}0.03^{*} \\
(0.02)\end{array}$ & $\begin{array}{l}-0.05 \\
(0.06)\end{array}$ \\
\hline \multirow[t]{2}{*}{ State } & $\begin{array}{c}2.78^{* * *} \\
(0.21)\end{array}$ & $\begin{array}{c}0.95^{* * *} \\
(0.09)\end{array}$ & $\begin{array}{c}0.88^{* * *} \\
(0.03)\end{array}$ & $\begin{array}{c}0.47^{* *} \\
(0.23)\end{array}$ & $\begin{array}{c}0.16^{* * *} \\
(0.05)\end{array}$ & $\begin{array}{c}0.06^{* *} \\
(0.03)\end{array}$ & $\begin{array}{l}-0.07 \\
(0.13)\end{array}$ & $\begin{array}{c}0.33^{* * *} \\
(0.10)\end{array}$ \\
\hline & \multicolumn{8}{|c|}{ Panel B: IV } \\
\hline County & $\begin{array}{c}0.78^{* * *} \\
(0.08)\end{array}$ & $\begin{array}{c}0.28^{* * *} \\
(0.08)\end{array}$ & $\begin{array}{c}0.21^{* * *} \\
(0.04)\end{array}$ & $\begin{array}{c}0.11^{* * *} \\
(0.03)\end{array}$ & $\begin{array}{c}0.05^{* * *} \\
(0.01)\end{array}$ & $\begin{array}{c}0.02^{* * *} \\
(0.01)\end{array}$ & $\begin{array}{l}-0.01 \\
(0.02)\end{array}$ & $\begin{array}{c}0.13 \\
(0.08)\end{array}$ \\
\hline County +100 miles & $\begin{array}{c}2.49 * * * \\
(0.18)\end{array}$ & $\begin{array}{c}0.95^{* * *} \\
(0.13)\end{array}$ & $\begin{array}{c}0.73^{* * *} \\
(0.05)\end{array}$ & $\begin{array}{c}0.45^{* * *} \\
(0.05)\end{array}$ & $\begin{array}{c}0.13^{* * *} \\
(0.02)\end{array}$ & $\begin{array}{c}0.07^{* * *} \\
(0.01)\end{array}$ & $\begin{array}{c}0.04 \\
(0.03)\end{array}$ & $\begin{array}{l}-0.00 \\
(0.06)\end{array}$ \\
\hline State & $\begin{array}{c}3.34^{* * *} \\
(0.55)\end{array}$ & $\begin{array}{c}1.21^{* * *} \\
(0.23)\end{array}$ & $\begin{array}{c}0.91^{* * *} \\
(0.03)\end{array}$ & $\begin{array}{l}0.86^{*} \\
(0.48)\end{array}$ & $\begin{array}{c}0.20^{* *} \\
(0.08)\end{array}$ & $\begin{array}{l}0.10^{*} \\
(0.05)\end{array}$ & $\begin{array}{l}-0.36 \\
(0.36)\end{array}$ & $\begin{array}{c}0.42^{* * *} \\
(0.10)\end{array}$ \\
\hline
\end{tabular}

Notes: Each coefficient represents a separate regression. County +100 miles includes all economic activity from counties within 100 miles radius. Standard errors, clustered by state-year (or state), are in parentheses. There are 24,646 (408) observations in each regression. The county sample excludes counties with 446 or fewer employees in 2004 (2 percent of all counties). 
Table 4: Effects of Fracking on Crime Rates

Dependent Variable: One-Year Change in Crimes per 1000 People Main Independent Variable: Oil and Natural Gas Value (\$Millions)

from Wells Opened in Current Year Per Capita
(1)
$(2)$
(3)
(4)
(5)
(6)
(7)
(8)

Property Violent Murder Rape Robbery Assault Larceny Motor Vehicle

\begin{tabular}{|c|c|c|c|c|c|c|c|c|}
\hline & Crime & Crime & 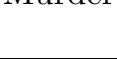 & . & 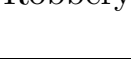 & 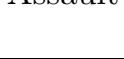 & -5 & Theft \\
\hline$\overline{\text { OLS }}$ & $\begin{array}{c}-1.14 \\
(11.53)\end{array}$ & $\begin{array}{c}1.01 \\
(4.74)\end{array}$ & $\begin{array}{c}0.17 \\
(0.21)\end{array}$ & $\begin{array}{c}0.65 \\
(0.55)\end{array}$ & $\begin{array}{l}-0.24 \\
(0.27)\end{array}$ & $\begin{array}{c}0.44 \\
(4.58)\end{array}$ & $\begin{array}{c}3.64 \\
(8.63)\end{array}$ & $\begin{array}{c}1.91 \\
(1.48)\end{array}$ \\
\hline IV & $\begin{array}{c}-9.60 \\
(44.77)\end{array}$ & $\begin{array}{c}3.88 \\
(11.24)\end{array}$ & $\begin{array}{l}0.76^{*} \\
(0.42)\end{array}$ & $\begin{array}{l}-0.07 \\
(1.33)\end{array}$ & $\begin{array}{l}-0.33 \\
(0.88)\end{array}$ & $\begin{array}{c}3.52 \\
(11.46)\end{array}$ & $\begin{array}{c}5.64 \\
(35.89)\end{array}$ & $\begin{array}{c}0.18 \\
(2.81)\end{array}$ \\
\hline Mean Dep. Var. & 63.73 & 7.81 & 0.10 & 0.73 & 1.04 & 5.93 & 42.53 & 4.09 \\
\hline
\end{tabular}

Notes: Each coefficient represents a separate regression. County +100 miles includes all economic activity from counties within 100 miles radius. Standard errors, clustered by state-year (or state), are in parentheses. There are 24,646 (408) observations in each regression. The county sample excludes counties with 446 or fewer employees in 2004 (2 percent of all counties). 


\section{Appendix}

Figure A1: Wage Income and Other Income Effects within a Given Distance (OLS)

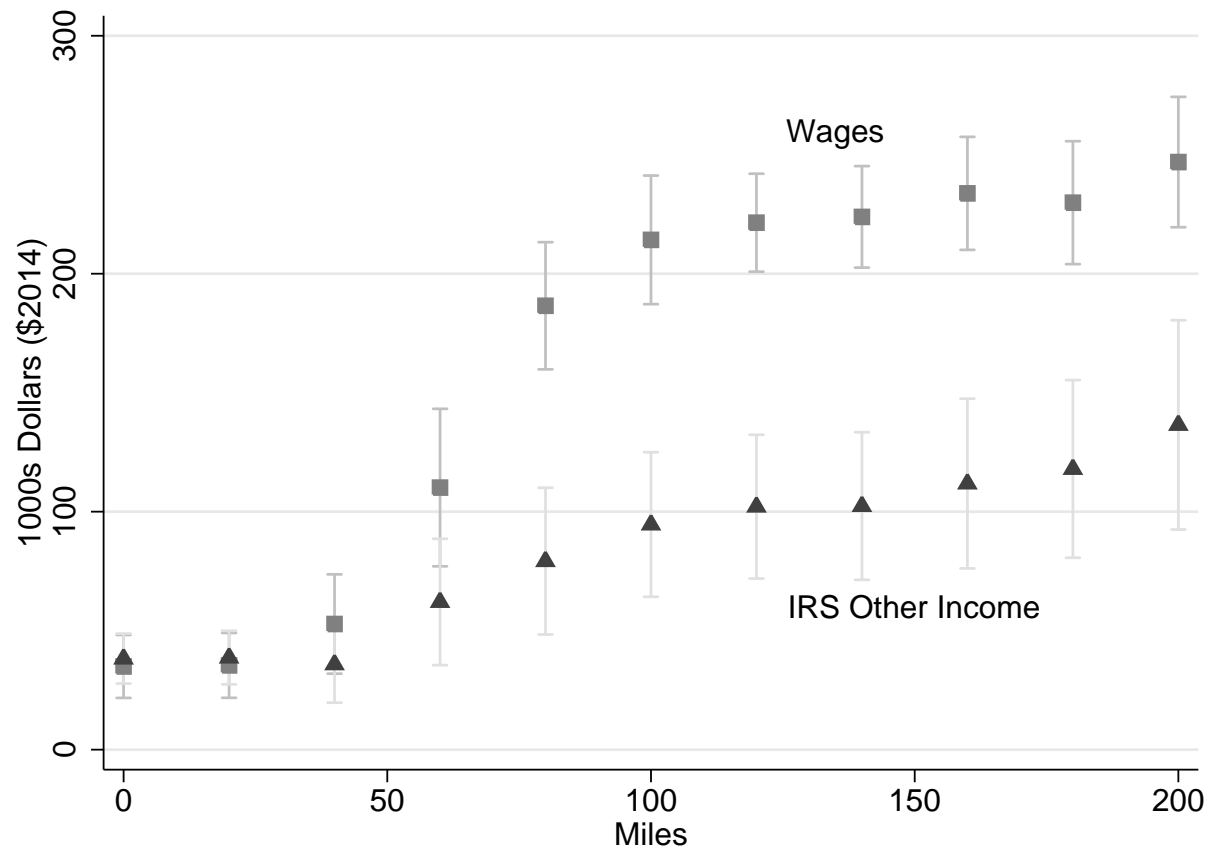

Notes: We estimate the aggregate one-year change in annual income per capita for circles of various radii. We include all counties for whom the distance between the centroids of the originating county and each other county is within a given distance. We regress this measure on the aggregated total value (in millions of dollars) from wells opened in the current year per capita within the corresponding circle. We control for county and year fixed effects. The figure reports the coefficient estimates and the 95 percent confidence interval where the standard errors are clustered by state-year. 
Figure A2: Wage Income Effects within a Given Distance by Fuel Type

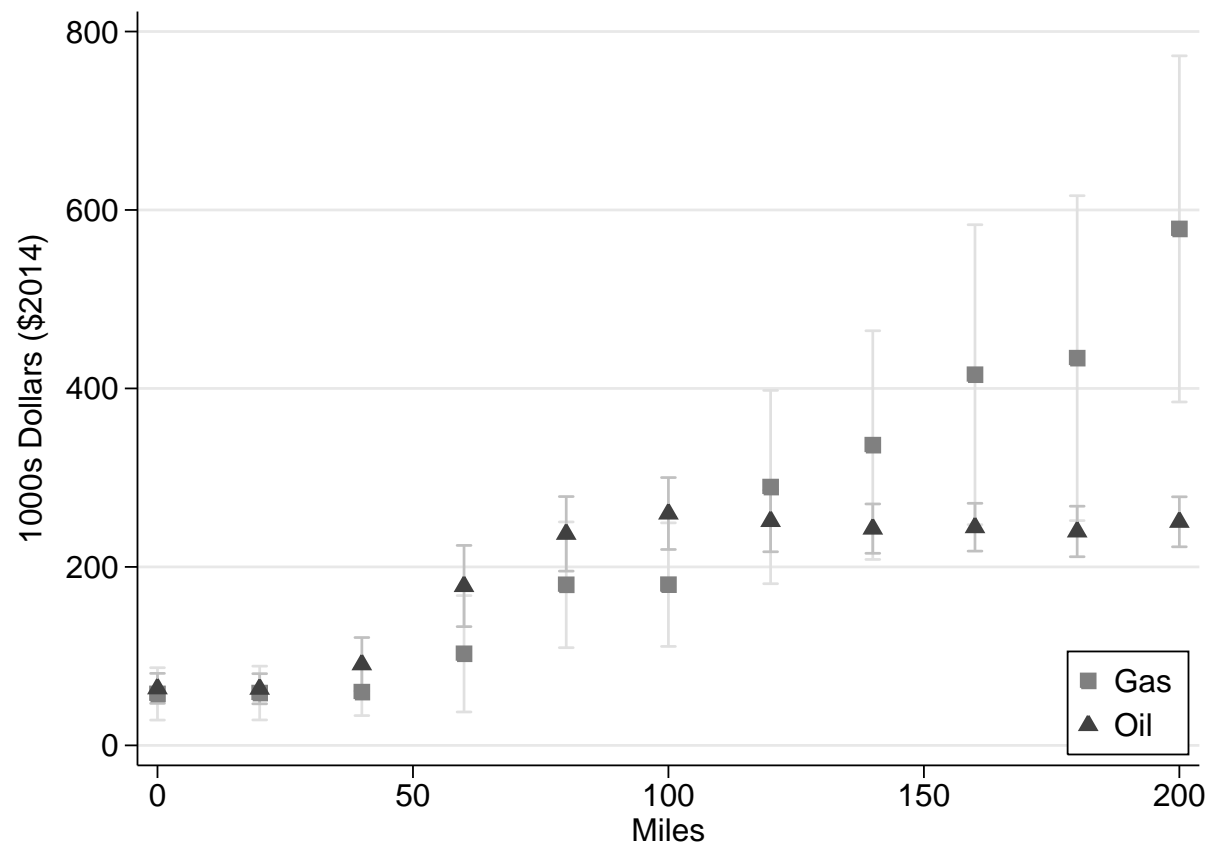

Notes: We estimate the aggregate one-year change in annual wages per capita for circles of various radii. We include all counties for whom the distance between the centroids of the originating county and each other county is within a given distance. We regress this measure on the aggregated total value (in millions of dollars) from wells opened in the current year per capita within the corresponding circle. We control for county and year fixed effects. The figure reports the coefficient estimates and the 95 percent confidence interval where the standard errors are clustered by state-year. 
Table A1: Comparison of Historic Population and Income by Group

\begin{tabular}{lcccc}
\multicolumn{5}{c}{ Panel A: Summary Statistics for 2004 by Group } \\
\hline Group & Observations & Population & $\begin{array}{c}\text { Income } \\
\text { (millions) }\end{array}$ & Wage Rate \\
\hline 1 & 2,113 & 42,609 & $\$ 1,680$ & $\$ 38,310$ \\
& & $(126,956)$ & $(6,540)$ & $(12,762)$ \\
2 & \multirow{4}{*}{827} & 35,118 & $\$ 1,300$ & $\$ 39,576$ \\
& \multirow{2}{*}{116} & $(175,911)$ & $(7,820)$ & $(12,828)$ \\
3 & & 54,576 & $\$ 2,450$ & $\$ 38,885$ \\
& \multirow{4}{*}{4} & $(182,231)$ & $(9,560)$ & $(12,963)$ \\
& & 67,572 & $\$ 2,570$ & $\$ 41,417$ \\
& & $(143,066)$ & $(5,930)$ & $(14,152)$ \\
\hline
\end{tabular}

Panel B: T-Statistics of Differences in Means across Groups

\begin{tabular}{r|ccc} 
Population & 2 & 3 & 4 \\
\hline 1 & -1.29 & 0.96 & 0.92 \\
2 & & 1.11 & 0.87 \\
3 & & & 0.31 \\
Income & 2 & 3 & 4 \\
\hline 1 & -1.35 & 1.19 & 0.64 \\
2 & & 1.44 & 0.77 \\
3 & & & 0.05 \\
Wage Rate & 2 & 3 & 4 \\
\hline 1 & 2.42 & 0.47 & 1.14 \\
2 & & -0.54 & 0.66 \\
3 & & & 0.82
\end{tabular}

Notes: Panel A reports the sample mean by group. Standard deviations are shown in parentheses. Groups are defined as follows: group 1 is the control group without any drilling; group 2 is early drillers starting in 2005 or 2006; group 3 is mid adopters starting in 2007-2010; and group 4 is late adopters starting in 2011 or 2012. Panel B shows the t-statistics of the differences between means for each pair of groups. 


\section{Table A2: Instrumental Variables First Stage Results}

Dependent Variable: Oil and Natural Gas Value (\$Millions) from Wells Opened in Current Year Per Capita

Main Independent Variable: Instrumented Oil and Natural Gas Value (\$Millions)

\begin{tabular}{|c|c|c|c|}
\hline & $\begin{array}{c}(1) \\
\text { All Fuels }\end{array}$ & $\begin{array}{l}(2) \\
\text { Oil }\end{array}$ & $\begin{array}{c}(3) \\
\text { Gas }\end{array}$ \\
\hline Instrument for all value & $\begin{array}{c}1.30 * * * \\
(0.37)\end{array}$ & & \\
\hline Instrument for oil value & & $\begin{array}{c}5.16^{* * *} \\
(0.44)\end{array}$ & \\
\hline Instrument for gas value & & & $\begin{array}{c}0.72^{* * *} \\
(0.14)\end{array}$ \\
\hline F Statistic & 12.19 & 135 & 25.49 \\
\hline
\end{tabular}

Notes: Each regression includes county fixed effects. Standard errors, clustered by state-year, are in parentheses. There are 24,646 observations in each regression. See text for a description of the instruments. 
Table A3: Effects on Wages by Population Size

Dependent Variable: One-Year Change in Wages and Salaries per Capita Main Independent Variable: Oil and Natural Gas Value (\$Millions)

\begin{tabular}{ccc} 
from Wells Opened in Current Year Per Capita \\
\hline & $(1)$ & $(2)$ \\
& OLS & IV \\
\hline Population: 0 to 1359 & $2,612^{* * *}$ & $3,079^{* * *}$ \\
& $(483)$ & $(971)$ \\
Pop: 1359 to 2425 & $31,732^{* * *}$ & 161,207 \\
& $(10,968)$ & $(119,530)$ \\
Pop: 2427 to 3767 & $45,734^{* * *}$ & $61,994^{* * *}$ \\
& $(8,149)$ & $(11,670)$ \\
Pop: 3767 to 5641 & $8,778^{* * *}$ & $32,076^{* *}$ \\
& $(1,251)$ & $(15,364)$ \\
Pop: 5652 to 8123 & $22,245^{* * *}$ & 115,136 \\
& $(3,699)$ & $(182,892)$ \\
Pop: 8123 to 12,205 & $269,730^{* * *}$ & $342,541^{* * *}$ \\
& $(68,945)$ & $(70,682)$ \\
Pop: 12,232 to 17,496 & $135,300^{* * *}$ & $263,980^{* * *}$ \\
& $(48,048)$ & $(98,353)$ \\
Pop: 17,496 to 32,890 & $134,680^{* * *}$ & 804,687 \\
& $(51,462)$ & $(568,883)$ \\
Pop: 32,945 to 77,334 & $69,278^{*}$ & $116,803^{*}$ \\
& $(35,686)$ & $(68,681)$ \\
Pop: Above 77,334 & $206,534^{* *}$ & 28,393 \\
& $(85,082)$ & $(395,732)$ \\
\hline *** p $<0.01, * *$ & $\mathrm{p}<0.05, *$ p $<0.10$
\end{tabular}

Notes: Each coefficient represents a separate regression. AGI is adjusted gross income. Standard errors, clustered by state-year, are in parentheses. There are 25,132 observations in each regression. 


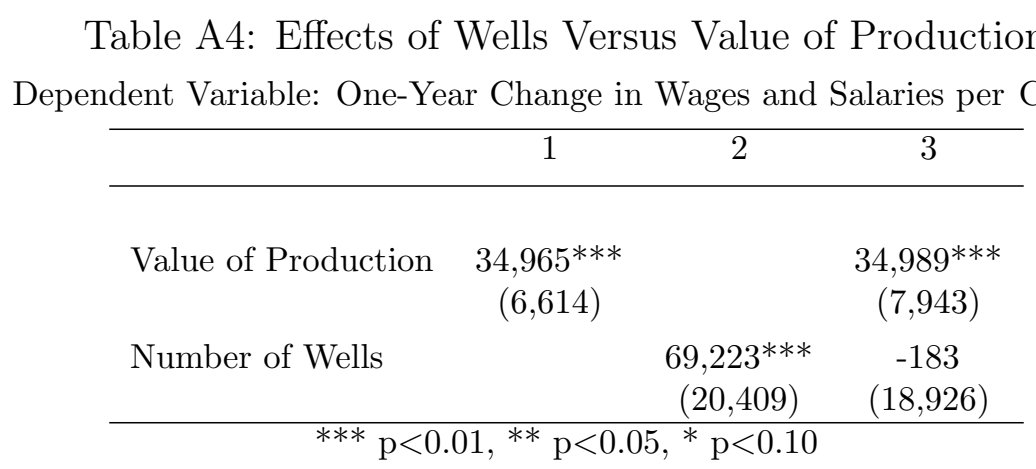

Notes: Production is the total value of oil and natural gas (\$Millions) from wells opened in the current year per capita. Wells is the number of these wells per capita. Standard errors, clustered by state-year, are in parentheses. There are 24,646 observations in each regression. The county sample excludes counties with 446 or fewer employees in 2004 (2 percent of all counties). 
Table A5: Effects of Fracking on Income by Fuel Type

Dependent Variable: One-Year Change in Wages and Salaries per Capita Main Independent Variable: Oil or Natural Gas Value (\$Millions) from Wells Opened in Current Year Per Capita

\begin{tabular}{|c|c|c|c|c|}
\hline & $\begin{array}{c}(1) \\
\text { BLS Wages }\end{array}$ & $\begin{array}{c}(2) \\
\text { IRS AGI }\end{array}$ & $\begin{array}{c}(3) \\
\text { IRS Wages }\end{array}$ & $\begin{array}{c}(4) \\
\text { IRS Other Inc }\end{array}$ \\
\hline & \multicolumn{4}{|c|}{ Panel A: Oil (OLS) } \\
\hline County & $\begin{array}{c}42,045^{* * *} \\
(8,905)\end{array}$ & $\begin{array}{c}57,671^{* * *} \\
(5,887)\end{array}$ & $\begin{array}{c}11,973^{* * *} \\
(2,525)\end{array}$ & $\begin{array}{c}46,129 * * * \\
(5,150)\end{array}$ \\
\hline County +100 miles & $\begin{array}{c}218,242^{* * *} \\
(16,407)\end{array}$ & $\begin{array}{c}154,534^{* * *} \\
(20,332)\end{array}$ & $\begin{array}{c}59,461^{* * *} \\
(7,075)\end{array}$ & $\begin{array}{c}96,451^{* * *} \\
(16,698)\end{array}$ \\
\hline \multirow[t]{2}{*}{ State } & $\begin{array}{c}274,137^{* * *} \\
(22,603)\end{array}$ & $\begin{array}{c}284,087^{* * *} \\
(38,430)\end{array}$ & $\begin{array}{c}90,565^{* * *} \\
(11,091)\end{array}$ & $\begin{array}{c}194,476 \text { *** } \\
(42,704)\end{array}$ \\
\hline & \multicolumn{4}{|c|}{ Panel B: Gas (OLS) } \\
\hline County & $\begin{array}{c}24,387^{* * *} \\
(6,356)\end{array}$ & $\begin{array}{c}38,783^{* * *} \\
(14,597)\end{array}$ & $\begin{array}{c}10,655^{* * *} \\
(4,063)\end{array}$ & $\begin{array}{c}26,445^{* *} \\
(12,692)\end{array}$ \\
\hline County +100 miles & $\begin{array}{c}175,836^{* * *} \\
(37,056)\end{array}$ & $\begin{array}{c}162,172^{* *} \\
(81,650)\end{array}$ & $\begin{array}{c}97,464^{* * *} \\
(24,105)\end{array}$ & $\begin{array}{c}77,027 \\
(63,709)\end{array}$ \\
\hline \multirow[t]{2}{*}{ State } & $\begin{array}{c}390,773^{* * *} \\
(72,295)\end{array}$ & $\begin{array}{c}-337,757^{* *} \\
(130,310)\end{array}$ & $\begin{array}{c}208,139 * * * \\
(56,775)\end{array}$ & $\begin{array}{c}-464,570^{* * *} \\
(131,161)\end{array}$ \\
\hline & \multicolumn{4}{|c|}{ Panel C: Oil (IV) } \\
\hline County & $\begin{array}{c}63,919 * * * \\
(8,410)\end{array}$ & $\begin{array}{c}79,051^{* * *} \\
(11,013)\end{array}$ & $\begin{array}{c}21,402^{* * *} \\
(3,867)\end{array}$ & $\begin{array}{c}58,154^{* * *} \\
(9,465)\end{array}$ \\
\hline County +100 miles & $\begin{array}{c}259,832^{* * *} \\
(20,138)\end{array}$ & $\begin{array}{c}190,049^{* * *} \\
(24,909)\end{array}$ & $\begin{array}{c}72,427^{* * *} \\
(9,146)\end{array}$ & $\begin{array}{c}120,028^{* * *} \\
(19,678)\end{array}$ \\
\hline \multirow[t]{2}{*}{ State } & $\begin{array}{c}279,777^{* * *} \\
(20,065)\end{array}$ & $\begin{array}{c}288,617^{* * *} \\
(51,918)\end{array}$ & $\begin{array}{c}97,432^{* * *} \\
(17,329)\end{array}$ & $\begin{array}{c}199,707^{* * *} \\
(47,710)\end{array}$ \\
\hline & \multicolumn{4}{|c|}{ Panel D: Gas (IV) } \\
\hline County & $\begin{array}{c}57,584^{* * *} \\
(14,658)\end{array}$ & $\begin{array}{c}105,255^{*} \\
(56,888)\end{array}$ & $\begin{array}{c}31,637^{* * *} \\
(7,757)\end{array}$ & $\begin{array}{c}67,534 \\
(48,617)\end{array}$ \\
\hline County +100 miles & $\begin{array}{c}180,129^{* * *} \\
(34,601)\end{array}$ & $\begin{array}{l}227,448^{*} \\
(127,393)\end{array}$ & $\begin{array}{c}128,907^{* * *} \\
(31,066)\end{array}$ & $\begin{array}{l}104,066 \\
(96,275)\end{array}$ \\
\hline State & $\begin{array}{c}444,764^{* * *} \\
(58,170)\end{array}$ & $\begin{array}{c}-240,615^{* *} \\
(94,946)\end{array}$ & $\begin{array}{c}269,854^{* * *} \\
(19,427)\end{array}$ & $\begin{array}{c}-405,763^{* * *} \\
(82,232)\end{array}$ \\
\hline
\end{tabular}

Notes: Each coefficient represents a separate regression. AGI is adjusted gross income. County +100 miles includes all economic activity from counties within 100 miles radius. Standard errors, clustered by state-year (or state), are in parentheses. There are 24,646 (408) observations in each regression. The county sample excludes counties with 446 or fewer employees in 2004 (2 percent of all counties). 
Table A6: Effects on Income by Direction of Price Shock

Dependent Variable: One-Year Change in Wages and Salaries per Capita Main Independent Variable: Oil and Natural Gas Value (\$Millions) from Wells Opened in Current Year Per Capita

\begin{tabular}{|c|c|c|c|c|}
\hline & $\begin{array}{c}(1) \\
\text { BLS Wages }\end{array}$ & $\begin{array}{c}(2) \\
\text { IRS AGI }\end{array}$ & $\begin{array}{c}(3) \\
\text { IRS Wages }\end{array}$ & $\begin{array}{c}(4) \\
\text { IRS Other Inc }\end{array}$ \\
\hline & \multicolumn{4}{|c|}{ Panel A: Rising Prices (OLS) } \\
\hline County & $\begin{array}{c}35,150^{* * *} \\
(9,277)\end{array}$ & $\begin{array}{c}46,415^{* * *} \\
(6,801)\end{array}$ & $\begin{array}{c}11,019^{* * *} \\
(2,125)\end{array}$ & $\begin{array}{c}35,322^{* * *} \\
(6,010)\end{array}$ \\
\hline County +100 miles & $\begin{array}{c}225,291^{* * *} \\
(23,597)\end{array}$ & $\begin{array}{c}161,723^{* * *} \\
(14,724)\end{array}$ & $\begin{array}{c}73,517^{* * *} \\
(6,436)\end{array}$ & $\begin{array}{c}95,506^{* * *} \\
(15,993)\end{array}$ \\
\hline \multirow[t]{2}{*}{ State } & $\begin{array}{c}325,391^{* * *} \\
(13,356)\end{array}$ & $\begin{array}{c}89,965 \\
(222,952)\end{array}$ & $\begin{array}{c}137,476^{* * *} \\
(38,670)\end{array}$ & $\begin{array}{c}11,181 \\
(178,458)\end{array}$ \\
\hline & \multicolumn{4}{|c|}{ Panel B: Falling Prices (OLS) } \\
\hline County & $\begin{array}{c}36,920^{* * *} \\
(8,916)\end{array}$ & $\begin{array}{c}62,953^{* * *} \\
(5,151)\end{array}$ & $\begin{array}{c}12,310^{* * *} \\
(2,552)\end{array}$ & $\begin{array}{c}50,457^{* * *} \\
(4,730)\end{array}$ \\
\hline County +100 miles & $\begin{array}{c}207,986^{* * *} \\
(16,035)\end{array}$ & $\begin{array}{c}188,463^{* * *} \\
(13,800)\end{array}$ & $\begin{array}{c}60,356^{* * *} \\
(7,206)\end{array}$ & $\begin{array}{c}128,529^{* * *} \\
(13,154)\end{array}$ \\
\hline \multirow[t]{2}{*}{ State } & $\begin{array}{c}222,662^{* * *} \\
(52,487)\end{array}$ & $\begin{array}{c}213,883^{* * *} \\
(71,627)\end{array}$ & $\begin{array}{c}28,680 \\
(37,606)\end{array}$ & $\begin{array}{c}200,931^{* *} \\
(96,184)\end{array}$ \\
\hline & \multicolumn{4}{|c|}{ Panel C: Rising Prices (IV) } \\
\hline County & $\begin{array}{c}61,273^{* * *} \\
(10,153)\end{array}$ & $\begin{array}{c}59,745^{* * *} \\
(19,726)\end{array}$ & $\begin{array}{c}21,485^{* * *} \\
(2,485)\end{array}$ & $\begin{array}{c}41,273^{* *} \\
(18,808)\end{array}$ \\
\hline County +100 miles & $\begin{array}{c}269,166^{* * *} \\
(21,142)\end{array}$ & $\begin{array}{c}189,897^{* * *} \\
(32,296)\end{array}$ & $\begin{array}{c}91,928^{* * *} \\
(6,161)\end{array}$ & $\begin{array}{c}110,168^{* * *} \\
(28,212)\end{array}$ \\
\hline \multirow[t]{2}{*}{ State } & $\begin{array}{c}362,350^{* * *} \\
(37,143)\end{array}$ & $\begin{array}{l}-217,711 \\
(458,640)\end{array}$ & $\begin{array}{c}234,005^{* *} \\
(92,901)\end{array}$ & $\begin{array}{l}-220,282 \\
(337,310)\end{array}$ \\
\hline & \multicolumn{4}{|c|}{ Panel D: Falling Prices (IV) } \\
\hline County & $\begin{array}{c}67,886^{* * *} \\
(6,897)\end{array}$ & $\begin{array}{c}113,307^{* * *} \\
(13,538)\end{array}$ & $\begin{array}{c}28,820^{* * *} \\
(5,556)\end{array}$ & $\begin{array}{c}76,868^{* * *} \\
(8,232)\end{array}$ \\
\hline County +100 miles & $\begin{array}{c}235,835^{* * *} \\
(13,298)\end{array}$ & $\begin{array}{c}221,229^{* * *} \\
(25,284)\end{array}$ & $\begin{array}{c}79,259^{* * *} \\
(12,545)\end{array}$ & $\begin{array}{c}142,620^{* * *} \\
(18,265)\end{array}$ \\
\hline State & $\begin{array}{c}356,493^{* *} \\
(156,650)\end{array}$ & $\begin{array}{c}263,035^{* * *} \\
(42,768)\end{array}$ & $\begin{array}{c}125,511 \\
(108,888)\end{array}$ & $\begin{array}{c}145,368 \\
(120,084)\end{array}$ \\
\hline
\end{tabular}

Notes: Each coefficient represents a separate regression. AGI is adjusted gross income. County +100 miles includes all economic activity from counties within 100 miles radius. Standard errors, clustered by state-year (or state), are in parentheses. There are 21,322 (306) observations in each regression. The county sample excludes counties with 446 or fewer employees in 2004 (2 percent of all counties). 
Table A7: Effects of Fracking on Wages and Salaries by Industry: Full Sample

Dependent Variable: One-Year Change in Wages and Salaries per Capita Main Independent Variable: Oil and Natural Gas Value (\$Millions) from Wells Opened in Current Year Per Capita

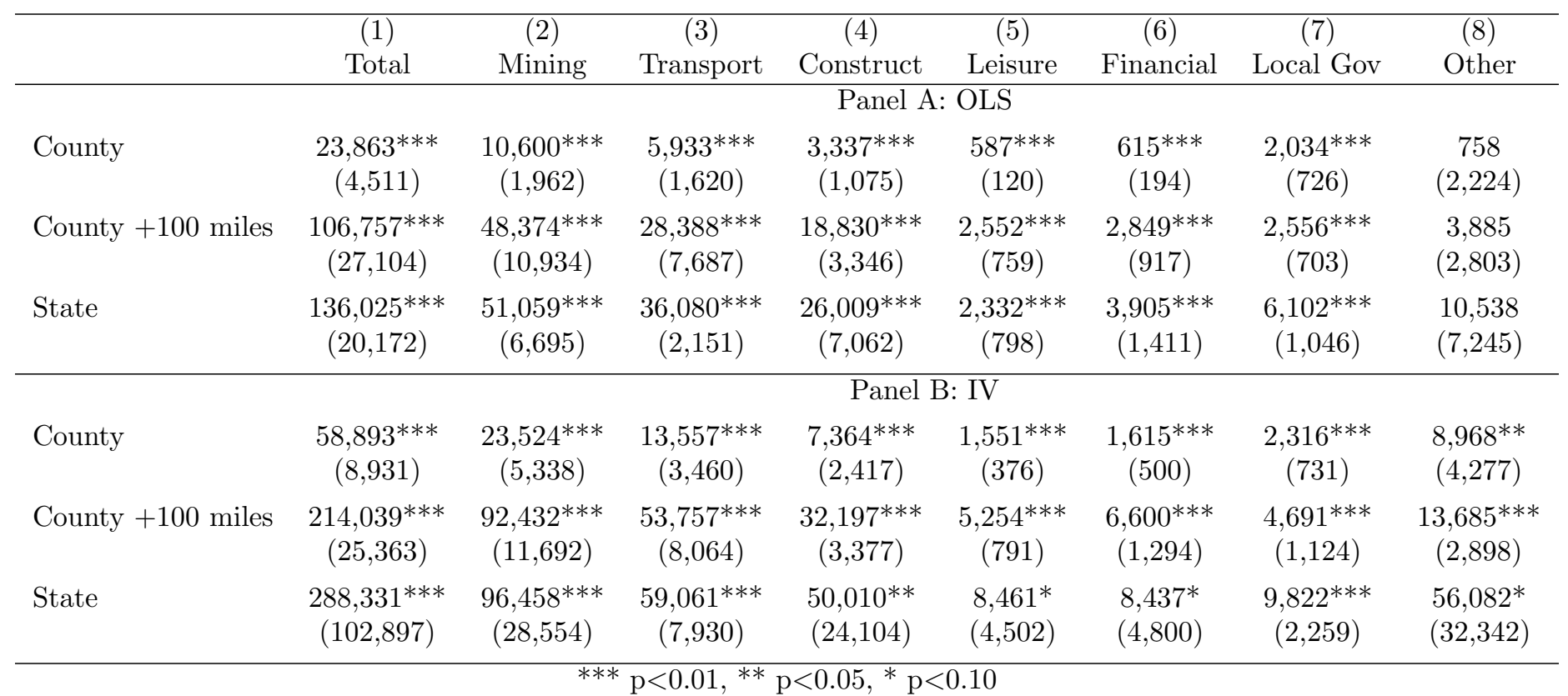

Notes: Each coefficient represents a separate regression. County +100 miles includes all economic activity from counties within 100 miles radius. Standard errors, clustered by state-year (or state), are in parentheses. There are 30,790 (510) observations in each regression. The county sample excludes counties with 446 or fewer employees in 2004 (2 percent of all counties). 
Table A8: Effects of Fracking on Employment by Industry: Full Sample

Dependent Variable: One-Year Change in Employment per Capita Main Independent Variable: Oil and Natural Gas Value (\$Millions) from Wells Opened in Current Year Per Capita

\begin{tabular}{|c|c|c|c|c|c|c|c|c|}
\hline & $\begin{array}{c}(1) \\
\text { Total }\end{array}$ & $\begin{array}{c}(2) \\
\text { Mining }\end{array}$ & $\begin{array}{c}(3) \\
\text { Transport }\end{array}$ & $\begin{array}{c}(4) \\
\text { Construct }\end{array}$ & $\begin{array}{c}(5) \\
\text { Leisure }\end{array}$ & $\begin{array}{c}(6) \\
\text { Financial }\end{array}$ & $\begin{array}{c}7) \\
\text { Local Gov }\end{array}$ & $\begin{array}{c}(8) \\
\text { Other }\end{array}$ \\
\hline & \multicolumn{8}{|c|}{ Panel A: OLS } \\
\hline County & $\begin{array}{c}0.31^{* * *} \\
(0.05)\end{array}$ & $\begin{array}{c}0.12^{* * *} \\
(0.03)\end{array}$ & $\begin{array}{c}0.08^{* * *} \\
(0.02)\end{array}$ & $\begin{array}{c}0.04^{* *} \\
(0.02)\end{array}$ & $\begin{array}{c}0.02^{* * *} \\
(0.01)\end{array}$ & $\begin{array}{c}0.01^{* * *} \\
(0.00)\end{array}$ & $\begin{array}{l}0.04^{*} \\
(0.02)\end{array}$ & $\begin{array}{l}-0.00 \\
(0.04)\end{array}$ \\
\hline County +100 miles & $\begin{array}{c}1.01^{* * *} \\
(0.30)\end{array}$ & $\begin{array}{c}0.42^{* * *} \\
(0.09)\end{array}$ & $\begin{array}{c}0.33^{* * *} \\
(0.09)\end{array}$ & $\begin{array}{c}0.20^{* * *} \\
(0.04)\end{array}$ & $\begin{array}{c}0.06 * * * \\
(0.02)\end{array}$ & $\begin{array}{c}0.02^{* * *} \\
(0.01)\end{array}$ & $\begin{array}{l}0.03^{*} \\
(0.02)\end{array}$ & $\begin{array}{l}-0.05 \\
(0.04)\end{array}$ \\
\hline \multirow[t]{2}{*}{ State } & $\begin{array}{c}1.08^{* * *} \\
(0.24)\end{array}$ & $\begin{array}{c}0.42^{* * *} \\
(0.09)\end{array}$ & $\begin{array}{c}0.39 * * * \\
(0.03)\end{array}$ & $\begin{array}{c}0.27^{* *} \\
(0.12)\end{array}$ & $\begin{array}{c}0.02 \\
(0.03)\end{array}$ & $\begin{array}{c}0.04^{* * *} \\
(0.01)\end{array}$ & $\begin{array}{c}0.02 \\
(0.08)\end{array}$ & $\begin{array}{l}-0.08 \\
(0.09)\end{array}$ \\
\hline & \multicolumn{8}{|c|}{ Panel B: IV } \\
\hline County & $\begin{array}{c}0.73^{* * *} \\
(0.11)\end{array}$ & $\begin{array}{c}0.27^{* * *} \\
(0.06)\end{array}$ & $\begin{array}{c}0.19^{* * *} \\
(0.04)\end{array}$ & $\begin{array}{c}0.11^{* *} \\
(0.04)\end{array}$ & $\begin{array}{c}0.04^{* * *} \\
(0.01)\end{array}$ & $\begin{array}{c}0.02^{* * *} \\
(0.01)\end{array}$ & $\begin{array}{c}0.01 \\
(0.02)\end{array}$ & $\begin{array}{c}0.09 \\
(0.07)\end{array}$ \\
\hline County +100 miles & $\begin{array}{c}2.24^{* * *} \\
(0.27)\end{array}$ & $\begin{array}{c}0.86^{* * *} \\
(0.11)\end{array}$ & $\begin{array}{c}0.64^{* * *} \\
(0.09)\end{array}$ & $\begin{array}{c}0.40 * * * \\
(0.05)\end{array}$ & $\begin{array}{c}0.12^{* * *} \\
(0.02)\end{array}$ & $\begin{array}{c}0.07 * * * \\
(0.01)\end{array}$ & $\begin{array}{l}0.05^{*} \\
(0.03)\end{array}$ & $\begin{array}{c}0.02 \\
(0.05)\end{array}$ \\
\hline State & $\begin{array}{c}2.79^{* *} \\
(1.19)\end{array}$ & $\begin{array}{c}0.98^{* *} \\
(0.40)\end{array}$ & $\begin{array}{c}0.71^{* * *} \\
(0.14)\end{array}$ & $\begin{array}{c}0.60 \\
(0.36)\end{array}$ & $\begin{array}{c}0.14 \\
(0.10)\end{array}$ & $\begin{array}{c}0.09 \\
(0.06)\end{array}$ & $\begin{array}{l}-0.24 \\
(0.32)\end{array}$ & $\begin{array}{c}0.51 \\
(0.45)\end{array}$ \\
\hline
\end{tabular}

Notes: Each coefficient represents a separate regression. County +100 miles includes all economic activity from counties within 100 miles radius. Standard errors, clustered by state-year (or state), are in parentheses. There are 30,790 (510) observations in each regression. The county sample excludes counties with 446 or fewer employees in 2004 ( 2 percent of all counties). 
Table A9: Effects on Income by Period (IV)

Dependent Variable: One-Year Change in Wages and Salaries per Capita Main Independent Variable: Oil and Natural Gas Value (\$Millions) from Wells Opened in Current Year Per Capita

\begin{tabular}{|c|c|c|c|c|}
\hline & $\begin{array}{c}(1) \\
\text { BLS Wages }\end{array}$ & $\begin{array}{c}(2) \\
\text { IRS AGI }\end{array}$ & $\begin{array}{c}(3) \\
\text { IRS Wages }\end{array}$ & $\begin{array}{c}(4) \\
\text { IRS Other Inc }\end{array}$ \\
\hline & \multicolumn{4}{|c|}{ Panel A: Years 2005 to 2008} \\
\hline County & $\begin{array}{c}24,809 \\
(28,417)\end{array}$ & $\begin{array}{l}122,645 \\
(99,025)\end{array}$ & $\begin{array}{c}8,411 \\
(11,529)\end{array}$ & $\begin{array}{l}127,242 \\
(95,093)\end{array}$ \\
\hline County +100 miles & $\begin{array}{c}321,311^{* *} \\
(132,388)\end{array}$ & $\begin{array}{c}856,955^{* *} \\
(400,983)\end{array}$ & $\begin{array}{c}179,186^{* *} \\
(70,223)\end{array}$ & $\begin{array}{c}651,513^{* *} \\
(320,696)\end{array}$ \\
\hline \multirow[t]{2}{*}{ State } & $\begin{array}{c}190,330 \\
(450,063)\end{array}$ & $\begin{array}{c}398,764 \\
(913,910)\end{array}$ & $\begin{array}{c}7,736 \\
(331,465)\end{array}$ & $\begin{array}{c}493,508 \\
(485,941)\end{array}$ \\
\hline & \multicolumn{4}{|c|}{ Panel B: Years 2009 to 2011} \\
\hline County & $\begin{array}{c}86,945^{* * *} \\
(10,098)\end{array}$ & $\begin{array}{c}127,750^{* * *} \\
(26,267)\end{array}$ & $\begin{array}{c}36,830^{* * *} \\
(8,321)\end{array}$ & $\begin{array}{c}92,293^{* * *} \\
(21,742)\end{array}$ \\
\hline County +100 miles & $\begin{array}{c}289,763^{* * *} \\
(26,186)\end{array}$ & $\begin{array}{c}307,196^{* * *} \\
(41,755)\end{array}$ & $\begin{array}{c}94,344^{* * *} \\
(14,005)\end{array}$ & $\begin{array}{c}219,169^{* * *} \\
(39,283)\end{array}$ \\
\hline State & $\begin{array}{c}144,075^{* *} \\
(59,399)\end{array}$ & $\begin{array}{c}61,994 \\
(330,931)\end{array}$ & $\begin{array}{c}13,637 \\
(40,599)\end{array}$ & $\begin{array}{c}96,061 \\
(264,040)\end{array}$ \\
\hline & \multicolumn{4}{|c|}{ Panel C: Years 2012 to 2014} \\
\hline County & $\begin{array}{c}174,160 \\
(105,658)\end{array}$ & & & \\
\hline County +100 miles & $\begin{array}{l}2,284,047^{*} \\
(1,242,824)\end{array}$ & & & \\
\hline State & $\begin{array}{l}-646,702^{*} \\
(333,327)\end{array}$ & & & \\
\hline
\end{tabular}

Notes: Each coefficient represents a separate regression. AGI is adjusted gross income. County +100 miles includes all economic activity from counties within 100 miles radius. Standard errors, clustered by state-year (or state), are in parentheses. There are 12,324, 9,239, and 9,237 (204, 153, and 153) observations for Panels A, B, and C, respectively. The county sample excludes counties with 446 or fewer employees in 2004 (2 percent of all counties). 